\title{
Control of Salmonella Enteritidis on food contact surfaces with bacteriophage PVP-SE2
}

\author{
Catarina Milho (D), Maria Daniela Silva (D), Luís Melo (D), Sílvio Santos (D), Joana Azeredo (D) and \\ Sanna Sillankorva iD \\ Centre of Biological Engineering, LIBRO - Laboratório de Investigação em Biofilmes Rosário Oliveira, University of Minho, \\ Braga, Portugal
}

ABSTRACT

Salmonella is one of the worldwide leading foodborne pathogens responsible for illnesses and hospitalizations, and its capacity to form biofilms is one of its many virulence factors. This work evaluated (bacterio)phage control of adhered and biofilm cells of Salmonella Enteritidis on three different substrata at refrigerated and room temperatures, and also a preventive approach in poultry skin. PVP-SE2 phage was efficient in reducing both 24- and 48-h old Salmonella biofilms from polystyrene and stainless steel causing 2 to $5 \mathrm{log}$ CFU cm${ }^{-2}$ reductions with a higher killing efficiency at room temperature. PVP-SE2 phage application on poultry skins reduced levels of Salmonella. Freezing phage-pretreated poultry skin samples had no influence on the viability of phage PVP-SE2 and their in vitro contamination with $S$. Enteritidis provided evidence that phages prevented their further growth. Although not all conditions favor phage treatment, this study endorses their use to prevent and control foodborne pathogen colonization of surfaces.
ARTICLE HISTORY

Received 25 April 2018

Accepted 9 July 2018

\section{KEYWORDS}

Salmonella; bacteriophage; biofilm; control; prevention

\section{Introduction}

Foodborne bacteria continue to be a major cause of illnesses in humans around the world, causing severe threats to human health and safety. Two million deaths are estimated to occur annually due to illnesses related to contaminated food and water, according to the World Health Organization (WHO 2015). Hence, food safety constitutes an increasing worldwide public health concern, in which Salmonella remains one of the most common causes of reported food poisoning events (WHO 2015; European Food Safety Authority and European Centre for Disease Prevention and Control 2016). The disease caused by Salmonella, salmonellosis, is the result of ingestion of this bacterium, and it shows symptoms such as diarrhea, fever and abdominal pain that occur 12 to $72 \mathrm{~h}$ after consumption of contaminated food (CDC 2018a). The leading food sources identified for human salmonellosis are poultry products, in particular chicken products (Finstad et al. 2012; WHO 2018). During the different stages of food processing, from production to consumption, products are susceptible to crosscontamination, particularly in the case of poultry meat products (Grant et al. 2016). Improper handling by the consumer can also contribute to increased rates of infection (DuPont 2007).

The ecology and occurrence of Salmonella serovars in poultry compared to those directly associated with human salmonellosis remain difficult to quantify owing to serovar variability in culture media recovery (Mead et al. 2010). Salmonella enterica serovar Enteritidis is one of the most reported serovars related to salmonellosis outbreaks (CDC 2018b).

Problems related to Salmonella have significantly increased due to their growing antimicrobial resistance and also because of their inherent capacity to adhere to surfaces and consequently form biofilms (Joseph et al. 2001; Helke et al. 2017). Bacteria within biofilms have an increased resistance to antibiotics, disinfectants, surfactants, and other products with antimicrobial activity (Steenackers et al. 2012).

Phages are viruses that infect bacterial cells using the host's machinery to create new progeny. Because of their ability to kill bacteria, they appear to be a good alternative to other products usually used for this purpose (antimicrobials, disinfectants) (Gutiérrez et al. 2016). Phages present many advantages over traditional antibiotics, since they are specific and efficient against their target bacteria, thereby reducing

CONTACT Sanna Sillankorva s.sillankorva@deb.uminho.pt

4 Supplemental material for this paper is available online at https://doi.org/10.1080/08927014.2018.1501475.

(C) 2018 Informa UK Limited, trading as Taylor \& Francis Group 
the destruction of the host's normal flora (Clark and March 2006). They are also innocuous for humans, and they persist only as long as the target pathogen is present (Ashelford et al. 2003; Hanlon 2007).

In the food industry, the use of new phages and commercially available phage products has recently increased, especially owing to the good results for pathogen reduction reported by several authors (Atterbury et al. 2003; Goode et al. 2003; Carlton et al. 2005; Higgins et al. 2005). Also, the FDA's first approved phage product, Listex ${ }^{\mathrm{TM}} \mathrm{P} 100$, to control Listeria monocytogenes in foods, was a strong incentive for the scientific community to start applying phages to food products (FDA and Department of Health and Human Services 2006). Currently, there are several phage-based products approved by the FDA including PhageGuard Listex (previously known as Listex $\left.{ }^{\mathrm{TM}} \mathrm{P} 100\right)$, for Listeria, PhageGuard S (previously known as Salmonelex ${ }^{\mathrm{TM}}$ ), for Salmonella, ListShield $^{\mathrm{TM}}$, EcoShield ${ }^{\mathrm{TM}}$, SalmoFresh ${ }^{\mathrm{TM}}$. In a previous study, several Salmonella phages were isolated and characterized into different groups. Some of these phages were verified to be good candidates for phage biocontrol of contaminated poultry products, including PVP-SE2 phage (previously known as $\varphi 38$ (Sillankorva et al. 2010), which was used in the work described herein. The main goal of this work was to evaluate the in vitro efficacy of phage PVP-SE2 to infect adhered and biofilm cells of Salmonella Enteritidis on different surfaces, and minimize $S$. Enteritidis colonization of poultry skin surfaces.

\section{Materials and methods}

\section{Bacteria and phages}

Salmonella enterica serovar Enteritidis S1400 was used to propagate bacteriophage PVP-SE2 previously known as $\varphi 38$ (Sillankorva et al. 2010). The bacterium was grown at $37^{\circ} \mathrm{C}$ in liquid $\mathrm{LB}$ medium or in solid LB medium ( $\mathrm{LB}+1.5 \%\left(\mathrm{w} \mathrm{v}^{-1}\right)$ of agar). The LPS mutants of Salmonella enterica serovar Typhimurium LT2 used in this study were obtained from the Salmonella Genetic Stock Centre (University of Calgary, Alberta, Canada).

\section{Phage propagation and titration}

Salmonella phage PVP-SE2 was amplified using the plate lysis and elution method (Sillankorva et al. 2008b). Titration of the phage was performed according to Adams (1959).

\section{Transmission electron microscopy}

The morphology of phage particles was observed by transmission electron microscopy (TEM), as previously described (Melo et al. 2014). Briefly, phage particles were collected after centrifugation $(1 \mathrm{~h}, 25,000 \times g$, $4^{\circ} \mathrm{C}$ ). The pellet was washed twice in tap water using the same centrifugation conditions. Phages were deposited on copper grids with carbon-coated Formvar films, stained with $2 \%\left(\mathrm{w} \mathrm{v}^{-1}\right)$ uranyl acetate $(\mathrm{pH} 4.0)$ and imaged using a Philips EM 300 electron microscope, with magnification being monitored with T4 phage tails (Ackermann 2009).

\section{Phage one-step growth characteristics}

The one-step growth curve of phage PVP-SE2 was carried out as previously described (Sillankorva et al. 2008a). Briefly, $10 \mathrm{ml}$ of mid-exponential phase Salmonella culture were harvested by centrifugation $\left(7,000 \times g, 5 \mathrm{~min}, 4^{\circ} \mathrm{C}\right)$ and the pellet resuspended in $5 \mathrm{ml}$ of fresh $\mathrm{LB}$ to obtain an $\mathrm{OD}_{620}$ of 1.0. To this suspension, $5 \mathrm{ml}$ of phage were added to have a multiplicity of infection (MOI) of 0.001 . Phage PVPSE2 was allowed to adsorb for $5 \mathrm{~min}$ at room temperature. The mixture was centrifuged as above and the pellet resuspended in $10 \mathrm{ml}$ of fresh LB. Samples were taken every $5 \mathrm{~min}$, for $40 \mathrm{~min}$, and immediately plated.

\section{Phage DNA extraction, genome sequencing and annotation}

Phage DNA was extracted essentially as described previously (Melo et al. 2014). Purified phages were treated with $0.016 \%\left(\mathrm{v} \mathrm{v}^{-1}\right)$ L1 buffer $[300 \mathrm{mM} \mathrm{NaCl}, 100 \mathrm{mM}$ Tris/HCl (pH 7.5), $10 \mathrm{mM}$ EDTA, $0.2 \mathrm{mg} \mathrm{ml}^{-1}$ BSA, $20 \mathrm{mg} \mathrm{ml}^{-1}$ RNase A, $6 \mathrm{mg} \mathrm{ml}^{-1}$ DNase I] for $2 \mathrm{~h}$ at $37^{\circ} \mathrm{C}$. After thermal inactivation of the enzymes for $15 \mathrm{~min}$ at $70^{\circ} \mathrm{C}, 50 \mu \mathrm{g} \mathrm{m}{ }^{-1}$ of proteinase $\mathrm{K}, 20 \mathrm{mM}$ EDTA, and $1 \%\left(\mathrm{w} \mathrm{v}^{-1}\right)$ SDS were added and proteins were digested for $18 \mathrm{~h}$ at $56^{\circ} \mathrm{C}$. This was followed by phenol, phenol:chloroform:isoamyl alcohol (25:24:1, $\left.\left(\mathrm{v} \mathrm{v}^{-1}\right)\right)$ and chloroform extractions, respectively. DNA was precipitated with isopropanol (100\%) and $3 \mathrm{M}$ sodium acetate ( $\mathrm{pH} 4.6)$, centrifuged (15 min, $7,600 \times g, 4^{\circ} \mathrm{C}$ ), and the pellet air-dried and further resuspended in nuclease-free water (Cleaver Scientific). Genome sequencing was performed on a 454 sequencing platform (Plate-forme $\mathrm{d}^{\prime}$ Analyses Génomiques at Laval University, Québec city, QC, Canada) to 50-fold coverage. Sequence data were assembled using SeqMan NGen4 software (DNASTAR, Madison, WI, USA). 
Phage genomes were autoannotated, using MyRAST (Aziz et al. 2008) and the presence of non-annotated CDSs, along with genes in which the initiation codon was miscalled, were checked manually using Geneious 6.1.6 (Biomatters, Newark, NJ, USA). Potential frameshifts were checked with BLASTX (Altschul et al. 1997), and BLASTP was used to check for homologous proteins (Altschul et al. 1990), with an E-value threshold of $<1 \times 10^{-5}$ and at least $80 \%$ query. Pfam (Finn et al. 2014) and InterProScan (Finn et al. 2017) were used for protein motif search, with the same cutoff parameters as used with BLASTP. Proteins molecular weight and isoelectric point were determined using ExPASy Compute pI/Mw (Wilkins et al. 1999). The presence of transmembrane domains was predicted operating TMHMM (Käll and Sonnhammer 2002) and Phobius (Käll et al. 2004), and membrane proteins were annotated when both tools were in agreement. The search of tRNA encoding genes was performed using tRNAscan-SE (Schattner et al. 2005). Putative promoter regions were checked using PromoterHunter from phiSITE (Klucar et al. 2009) and were further manually verified. ARNold (Naville et al. 2011) was used to predict rho-independent terminators and the energy was calculated using Mfold (Zuker 2003). The complete genome sequences of PVP-SE2 was submitted to GenBank under the accession number MF431252.

\section{Stability of phage PVP-SE2 at refrigerated and frozen temperatures}

Stability of PVP-SE2 on poultry skins was assessed at refrigerated $\left(4^{\circ} \mathrm{C}\right)$ and frozen $\left(-18^{\circ} \mathrm{C}\right)$ temperatures. Briefly, poultry skin samples $(1 \mathrm{~cm} \times 1 \mathrm{~cm})$ were disinfected (Table S1), and to each skin square $100 \mu \mathrm{l}$ of phage PVP-SE2 were added at different concentrations $\left(10^{4}, 10^{5}\right.$ and $\left.10^{6} \mathrm{PFU} \mathrm{ml} \mathrm{m}^{-1}\right)$. Skins were dried for $30 \mathrm{~min}$ and after that they were transferred to the appropriate storage conditions $\left(4^{\circ} \mathrm{C}\right.$ and $\left.-18^{\circ} \mathrm{C}\right)$. To recover phage PVP-SE2 from the skin squares, samples were immerged in $1 \mathrm{ml}$ of SM buffer $\left(5.8 \mathrm{~g}^{-1}\right.$ $\mathrm{NaCl}, 2 \mathrm{~g} \mathrm{l}^{-1} \mathrm{MgSO}_{4} .7 \mathrm{H}_{2} \mathrm{O}, 50 \mathrm{ml} 1 \mathrm{M}$ Tris, $\mathrm{pH}$ 7.5) and vortexed for $30 \mathrm{~s}$. Serial dilutions were done in SM buffer for each phage PVP-SE2 concentration used and the plaque forming units (PFUs) determined. Samples were stored for 10 days with triplicate samples assessed every day.

\section{Susceptibility of surviving cells and LT2 mutants to phages}

Single colonies $(n=12)$ from each of the three independent phage treatments performed were randomly selected from the stainless steel (SS), polystyrene and poultry skin surfaces. The susceptibility of these colonies to four phages was tested according to a procedure previously described (Moons et al. 2013). The phages PVP-SE2, $\varphi 68$, PVP-SE1, and $\varphi 135$ have all been previously characterized (Sillankorva et al. 2010). PVP-SE2, $\varphi 68$, PVP-SE1, and $\varphi 135$ were also plated in Salmonella Typhimurium LT2 mutant strains that have different degrees of deletion in the lipopolysaccharide (LPS) chain (Figure S1). Briefly, $10 \mu \mathrm{l}$ of 10 fold serial dilutions of phage starting at $10^{9} \mathrm{PFU}$ $\mathrm{ml}^{-1}$ were added to the bacterial lawns of the mutant strains. Plates were incubated overnight at $37^{\circ} \mathrm{C}$, and lytic activity was checked for the formation of lysis areas and phage plaque turbidity.

\section{S. Enteritidis colonization of polystyrene and treatment with phage}

Biofilms of S. Enteritidis S1400 were formed at $22^{\circ} \mathrm{C}$ and $4{ }^{\circ} \mathrm{C}$, in 24 -well plates, under static conditions and without medium change to better mimic the handling/storage conditions of poultry products. For biofilm formation, $1 \mathrm{ml}$ of $S$. Enteritidis at $1 \times 10^{4} \mathrm{CFU}$ $\mathrm{ml}^{-1}$ prepared in LB was added to each well. Biofilms were formed for 1,24 , and $48 \mathrm{~h}$ at $22^{\circ} \mathrm{C}$, and for 4 , 24,48 , and $72 \mathrm{~h}$ at $4{ }^{\circ} \mathrm{C}$, washed once with saline solution $\left(\mathrm{NaCl} 0.9 \%\left(\mathrm{w} \mathrm{v}^{-1}\right)\right)$ and treated with phage PVP-SE2 at multiplicities of infection (MOIs) of 0.1, 1 and 10. For this, $250 \mu \mathrm{l}$ of LB and $750 \mu \mathrm{l}$ of phage were added to each well in order to obtain the right MOI. In the negative control, instead of $750 \mu \mathrm{l}$ of phage, $750 \mu \mathrm{l}$ of SM buffer were added. At the end of the treatment, biofilms were washed twice and $1 \mathrm{ml}$ of saline solution $\left(\mathrm{NaCl} 0.9 \%\left(\mathrm{w} \mathrm{v}^{-1}\right)\right)$ with ferric ammonium sulfate (FAS) at $2 \mathrm{mM}$ was added to each well. Microplates were sonicated (water bath sonicator, Sonic model SC-52, UK) for $6 \mathrm{~min}$, all wells scraped and the number of viable cells in each well was counted.

\section{S. Enteritidis colonization of SS and treatment with phage}

SS coupons (stainless steel S30400) measuring $1 \mathrm{~cm} \times 1 \mathrm{~cm}$ were disinfected by soaking in ethanol $96 \%\left(\mathrm{v} \mathrm{v}^{-1}\right)$ for $30 \mathrm{~min}$, washed with distilled water, dried for $30 \mathrm{~min}$ at $60^{\circ} \mathrm{C}$ and autoclaved at $121^{\circ} \mathrm{C}$ for $15 \mathrm{~min}$. The coupons were placed in 24 -well plates and contaminated with $S$. Enteritidis S1400. For this, $1 \mathrm{ml}$ of $S$. Enteritidis $\mathrm{S} 1400$ at $1 \times 10^{4} \mathrm{CFU} \mathrm{ml} \mathrm{m}^{-1}$ prepared in LB was added to each well. 24 and $48 \mathrm{~h}$ old biofilms were formed at $4{ }^{\circ} \mathrm{C}$ and $22^{\circ} \mathrm{C}$ under static 
conditions. After this, coupons were washed with $1 \mathrm{ml}$ of saline solution $\left(\mathrm{NaCl} 0.9 \%\left(\mathrm{w} \mathrm{v}^{-1}\right)\right)$, and to each well $250 \mu \mathrm{l}$ of LB medium plus $750 \mu \mathrm{l}$ of phage PVPSE2 were added. Phage PVP-SE2 was added at different MOIs (0.1, 1 and 10). In the negative control, instead of $750 \mu \mathrm{l}$ of phage, SM buffer was used. After incubation for 2, 5 or $24 \mathrm{~h}$, the coupons were washed with saline solution $\left(\mathrm{NaCl} 0.9 \%\left(\mathrm{w} \mathrm{v}^{-1}\right)\right)$, put in $1 \mathrm{ml}$ of saline solution $\left(\mathrm{NaCl} 0.9 \%\left(\mathrm{w} \mathrm{v}^{-1}\right)\right)$ with FAS at $2 \mathrm{mM}$, sonicated for $6 \mathrm{~min}$ (water bath sonicator, Sonic model SC-52, UK) and vortexed for $30 \mathrm{~s}$. To determine the number of viable cells in each coupon, CFU counts were performed.

\section{S. Enteritidis colonization of poultry skins and treatment with phage}

Poultry skin samples were cut into small squares $(1 \mathrm{~cm} \times 1 \mathrm{~cm})$ and immersed in different solutions and/or in an ultrasound bath for distinct periods of time (Table S1). This step was carried out to ensure that any effect observed was solely due to the added bacteria and not any other microorganisms, which could lead to variations in the interpretation of the results. After each treatment, viable cells were determined by CFU counts. Complete eradication of Salmonella from the skin samples was achieved after four distinct treatments: (1) acetic acid together with ultrasonic bath; (2) acetic acid $\left(45 \mathrm{~min}, 4^{\circ} \mathrm{C}\right)$; (3) lactic acid $\left(2 \mathrm{~min}, 22^{\circ} \mathrm{C}\right.$ ); and (4) ethanol $96 \%$ (30 s, $22^{\circ} \mathrm{C}$ ). Therefore, for all further experiments, the ethanol $\left(96 \%\left(\mathrm{v} \mathrm{v}^{-1}\right)\right)$ treatment was adopted since it was the fastest treatment tested and there was limited residual activity owing to subsequent evaporation. For this procedure, poultry skin squares $(1 \mathrm{~cm} \times 1 \mathrm{~cm})$ were immersed in ethanol $96 \%\left(\mathrm{v} \mathrm{v}^{-1}\right)$, washed with sterile distilled water, and frozen until further use. Frozen skin squares were placed in 24-well microplates. Each square was inoculated on top with $100 \mu \mathrm{l}$ of an overnight culture of $S$. Enteritidis S1400 diluted with fresh LB medium to a final concentration of $10^{4}$ $\mathrm{CFU} \mathrm{m} \mathrm{m}^{-1}$. The plates were incubated at $4{ }^{\circ} \mathrm{C}$ for 4 and $24 \mathrm{~h}$. After incubation, the skin samples were washed twice with saline solution $(\mathrm{NaCl} \quad 0.9 \%$ $\left(\mathrm{w} \mathrm{v}^{-1}\right)$ ), and PVP-SE2 $(100 \mu \mathrm{l})$ was added to the skin squares at MOIs of 10 and 100. Negative control assays were performed with $100 \mu \mathrm{l}$ of SM buffer instead of phage. Skin samples were incubated at $4{ }^{\circ} \mathrm{C}$ and phage infection was carried for 2, 5 and $24 \mathrm{~h}$. After the treatment, skin samples were washed with $1 \mathrm{ml}$ of saline solution $\left(\mathrm{NaCl} 0.9 \%\left(\mathrm{w} \mathrm{v}^{-1}\right)\right)$, put in $1 \mathrm{ml}$ of saline solution $\left(\mathrm{NaCl} 0.9 \%\left(\mathrm{w} \mathrm{v}^{-1}\right)\right)$ with FAS at $2 \mathrm{mM}$, vortexed for $30 \mathrm{~s}$ and counting of CFUs was performed.

\section{Phage PVP-SE2 pretreatment of poultry} skin samples and post-contamination with

\section{S. Enteritidis}

Phage PVP-SE2 solutions $(100 \mu \mathrm{l})$ at concentrations of $10^{4}, 10^{5}$, and $10^{6} \mathrm{PFU} \mathrm{m}{ }^{-1}$ were added to disinfected poultry skin squares $(1 \mathrm{~cm} \times 1 \mathrm{~cm})$ and incubated for $30 \mathrm{~min}$ at $4{ }^{\circ} \mathrm{C}$. After that, $S$. Enteritidis S1400 $\left(100 \mu \mathrm{l}\right.$ at $\left.10^{4} \mathrm{CFU} \mathrm{ml^{-1 }}\right)$ was spread on top of the skin samples, which were then incubated at $4{ }^{\circ} \mathrm{C}$ for 5, 24, and $48 \mathrm{~h}$. Negative controls were skin squares in which the $100 \mu \mathrm{l}$ of phage solution were replaced by $100 \mu \mathrm{l}$ of SM buffer. After incubation, skin samples were washed, vortexed for $30 \mathrm{~s}$ in $1 \mathrm{ml}$ of saline solution $\left(\mathrm{NaCl} 0.9 \%\left(\mathrm{w} \mathrm{v}^{-1}\right)\right)$ with FAS at $2 \mathrm{mM}$ and CFU counts were performed.

\section{Statistical analysis}

Statistical analysis of the results was performed using GraphPad Prism 6 (GraphPad Software, La Jolla, California, USA, www.graphpad.com). Mean and standard deviations (SD) were determined for the independent experiments and the results were presented as mean $\pm \mathrm{SD}$. Results were compared using two-way ANOVA, with Tukey's multiple comparison statistical test. Differences were considered statistically different if $p \leq 0.05$ (95\% confidence interval).

\section{Results}

\section{Phage PVP-SE2}

Phage PVP-SE2 was previously suggested as a good biocontrol agent due to its broad-host range (Sillankorva et al. 2010). The virion particle resembled phages belonging to the Jersey-like genus of the family Siphoviridae, having heads of $57 \mathrm{~nm}$, tails of $125 \mathrm{~nm}$ in length and $8 \mathrm{~nm}$ wide, and a base plate with three or more spikes (Figure 1A). Furthermore, this phage formed clear plaques, $3 \mathrm{~mm}$ in diameter, without a halo, in bacterial lawns on its host (data not shown). The one-step growth characteristics revealed that the latent period was $15 \mathrm{~min}$, with a rise period of $15 \mathrm{~min}$, thereby giving an average of 240 progeny phages per infected cell (Figure 1B).

Genome analysis revealed that PVP-SE2 is a virulent phage that does not encode genes related with lysogeny nor known toxins of bacterial origin (Figure 2). PVPSE2 has a linear dsDNA with 42,425 bp with a $G+C$ 

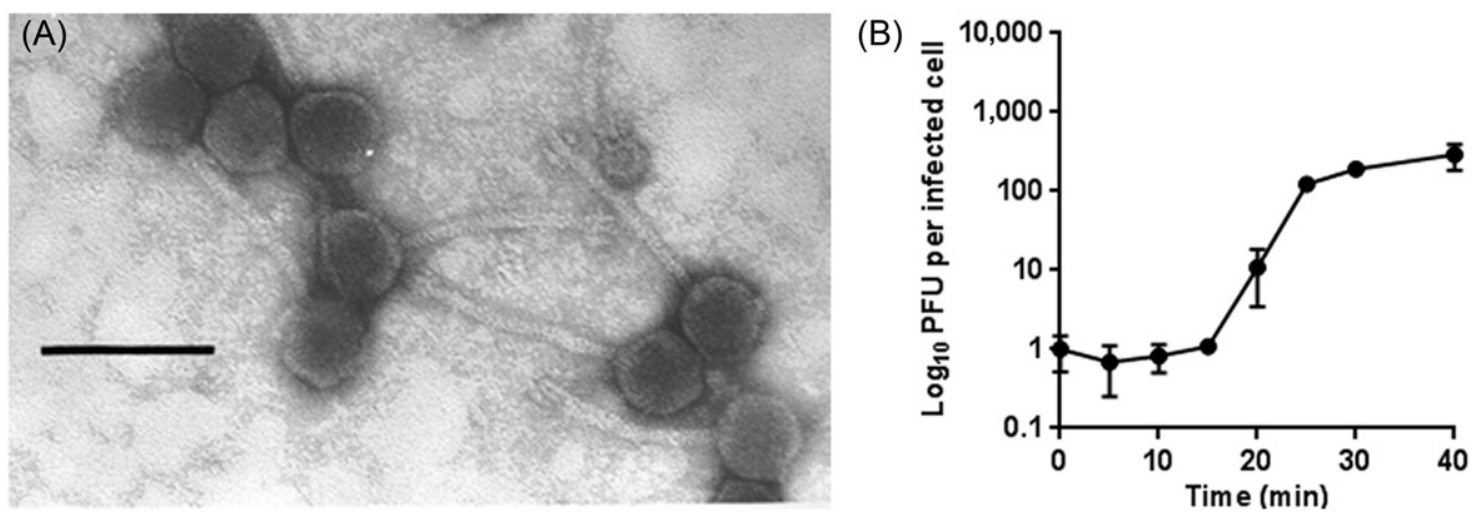

Figure 1. Phage PVP-SE2 characteristics. (A) TEM image of phage PVP-SE2, scale bar =100 nm; (B) one-step growth curve.

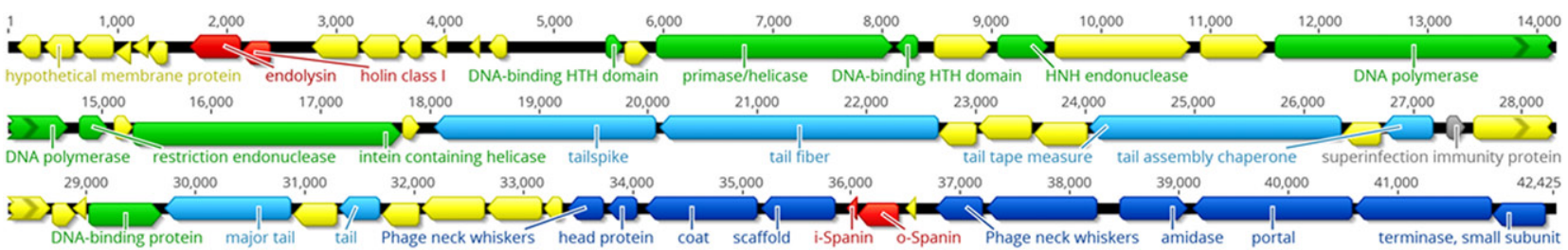

Figure 2. Linear map of phage PVP-SE2 genome sequence. The arrows represent the ORFs and point the direction of transcription.

content of $49.98 \%$. This phage encodes 59 putative coding DNA sequences (CDSs), tightly packed, occupying $92 \%$ of its genome (Table S2). From the predicted CDSs, 29 had an assigned function, and no unique proteins nor tRNA genes were identified. Fiftythree CDSs possess methionine as a start codon, while four and three CDSs start with GTG and TTG, respectively. Seventeen of the genes were rightward oriented, while 43 were leftward oriented. Overall, 11 promoters and 14 rho-independent terminators were found throughout the genome. Based on the predictions, the genome appeared to be organized into four functional modules (packaging, structure/morphogenesis, host lysis and replication/regulation) which fits the typical structure of most dsDNA phages (Figure 2).

Whole-genome comparison using BLASTN algorithm revealed that PVP-SE2 is highly homologous ( $>90 \%$ coverage, $>90 \%$ identity and an e-value of 0 ) to several Salmonella siphoviruses, namely of the genus Jerseyvirus, indicating that PVP-SE2 belongs to this genus. Overall, the analysis performed herein revealed that this phage is theoretically safe for Salmonella control on foods and surfaces.

\section{PVP-SE2 viability at refrigerated and freezing temperature conditions}

The viability and stability of phage PVP-SE2 on poultry skin samples were monitored over a 10-day period at $4{ }^{\circ} \mathrm{C}$ and $-18^{\circ} \mathrm{C}$, after the disinfection with
96\% ethanol, a treatment which had no effect on phage activity even after five days (data not shown). Test temperatures of $4{ }^{\circ} \mathrm{C}$ and $-18^{\circ} \mathrm{C}$ were chosen as they represent the most common temperatures used for the storage of poultry meat. The number of phage PVP-SE2 particles recovered from the samples stored at either $4{ }^{\circ} \mathrm{C}$ or $-18{ }^{\circ} \mathrm{C}$ remained relatively stable after 10 days, and there was no statistically significant loss of activity (Figure $3 \mathrm{~A}$ and $\mathrm{B}$ ), which suggests that after defrosting the phages are still capable of actively targeting Salmonella.

\section{Phage application to S. Enteritidis on different contact materials}

In food industry environments, Salmonella can be found in processing areas, such as walls, floors, pipes and drains and on food contact surfaces such as SS, aluminum, rubber or polystyrene (Steenackers et al. 2012). To study adhesion and biofilm formation, three surfaces were chosen: polystyrene; SS; and poultry skin. Although the study was designed to evaluate phage control of biofilms, in many circumstances, after in vitro contamination of the surfaces with Salmonella, cells only adhered and did not increase in number. Therefore, the results of phage control of adhered and biofilm cells are presented herein. At $22^{\circ} \mathrm{C} \mathrm{S}$. Enteritidis cells were allowed to adhere for $1 \mathrm{~h}$ to polystyrene after which phage treatment was immediately applied at varied time points 

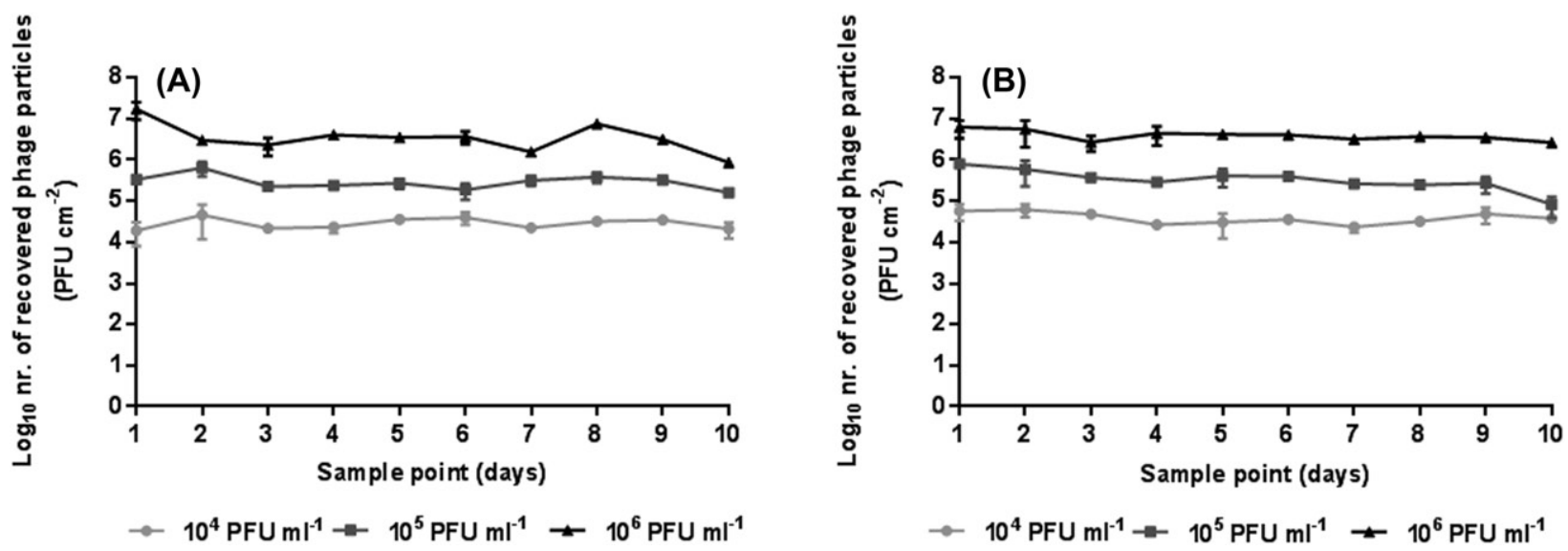

Figure 3. Phage PVP-SE2 viability following storage at (A) $4^{\circ} \mathrm{C}$ and (B) $-18^{\circ} \mathrm{C}$ for 10 days.

(Figure 4A). Although phage application for $2 \mathrm{~h}$ had no significant effect on biofilms adhered for $1 \mathrm{~h}$, treatment for 5 and $24 \mathrm{~h}$ significantly $(p<0.05)$ reduced the number of viable cells compared to the control samples that grew 10- to 100-fold in number. In general, these results show that higher reductions were obtained for lower MOIs (0.1 and 1), with the greatest decreases occurring when a MOI of 0.1 was used for treatment for 5 and $24 \mathrm{~h}$, respectively. Phage control of biofilms formed on polystyrene was studied for 24 and $48 \mathrm{~h}$-old $\mathrm{S}$. Enteritidis biofilms grown at $22^{\circ} \mathrm{C}$ (Figure $4 \mathrm{~B}$ and C). Salmonella levels reached $\sim 10^{6}$ CFU $\mathrm{cm}^{-2}$ and $10^{7} \mathrm{CFU} \mathrm{cm} \mathrm{cm}^{-2}$ in 24 and $48 \mathrm{~h}$-old biofilms, respectively. Treatment of both $24 \mathrm{~h}$ and $48 \mathrm{~h}$ old biofilms significantly $(p<0.05)$ decreased the number of cells compared to the control samples regardless of the phage:host ratios applied, with reductions ranging from $1.5 \log$ to $3.4 \log$ for $24 \mathrm{~h}$ biofilms (Figure 4B) and from 2.1 to $5.1 \log \mathrm{CFU}$ reductions in $48 \mathrm{~h}$-old biofilms. Overall, the greatest reduction in bacterial numbers was obtained with the lowest MOI used of 0.1 (Figure 4C). While PVP-SE2 clearly showed promising results at room temperature $\left(22^{\circ} \mathrm{C}\right)$, the same was not evident at refrigerated temperatures. At $4{ }^{\circ} \mathrm{C}$, phage control experiments were carried out between $4 \mathrm{~h}$ and $72 \mathrm{~h}$. Even though Salmonella is able to grow at refrigerated temperatures, at $4{ }^{\circ} \mathrm{C}$ the levels of cells after $4 \mathrm{~h}$ were similar to those at $72 \mathrm{~h}$ (Figure 5) reaching $\sim 2.1 \log \mathrm{CFU}$. Phage treatment applied to either $48 \mathrm{~h}$ or $72 \mathrm{~h}$ adhered cells had only a minor effect (Figure 5C and D) which although statistically significant $(p<0.05)$ resulted only in a maximum of a $0.5 \mathrm{log}$ reduction. SEM was used to assess biofilm formation at $22{ }^{\circ} \mathrm{C}$ on polystyrene prior to and after treatment with phage (Figure 6). After $24 \mathrm{~h}$, biofilms were mainly a layer of individual cells dispersed on the surface (Figure 6E and F) while after $48 \mathrm{~h}$ the cells entirely covered the surface of the coupon (Figure 6G and $\mathrm{H}$ ). Phage infection resulted in damaged cells, and a high amount of cell debris along with a few intact cells (Figure 7).

SS coupons were artificially contaminated with $S$. Enteritidis $S 1400$ and held for 24 and $48 \mathrm{~h}$ before being challenged with phage PVP-SE2 (Figure 8). At $22{ }^{\circ} \mathrm{C}$, phage treatment applied to $24 \mathrm{~h}$ biofilms caused reductions of up to $1.9 \log \mathrm{CFU}$ for all MOIs and periods of treatment (Figure 8A). Unlike the case with polystyrene, the main observation at $22^{\circ} \mathrm{C}$ was that PVP-SE2 was more efficient at reducing the number of viable cells in younger $(24 \mathrm{~h})$ than in older biofilms (48 h), where only $1.4 \log \mathrm{CFU}$ was observed (Figure 8B). At $4{ }^{\circ} \mathrm{C}$, treatment of the $24 \mathrm{~h}$ contaminated surfaces did not have a pronounced effect on reducing Salmonella numbers despite the numbers being statistically different compared to the control (Figure 8C). At this temperature, phages applied to $48 \mathrm{~h}$ contaminated surfaces only slightly limited the growth of cells when a MOI of 0.1 was used (Figure 8D). SEM images (Figure 6) of biofilms on SS showed that these biofilms were structurally different from those formed on polystyrene with microcolonies observed on $24 \mathrm{~h}$ biofilms (Figure $6 \mathrm{~A}$ and $\mathrm{B}$ ) and a dense biofilm after $48 \mathrm{~h}$ (Figure 6C and D). The same cell damage and debris observed in Figure 7 (polystyrene) was also observed on SS coupons (data not shown).

In this work the effect of phage control was further tested as well as Salmonella colonization inhibition on phage pretreated poultry skins as a potential strategy that could be used before the industrial packaging of poultry meat. However, before these experiments it was important to ensure that all skin surfaces were both Salmonella-free and free from other species that might be present in the skin since these could affect 

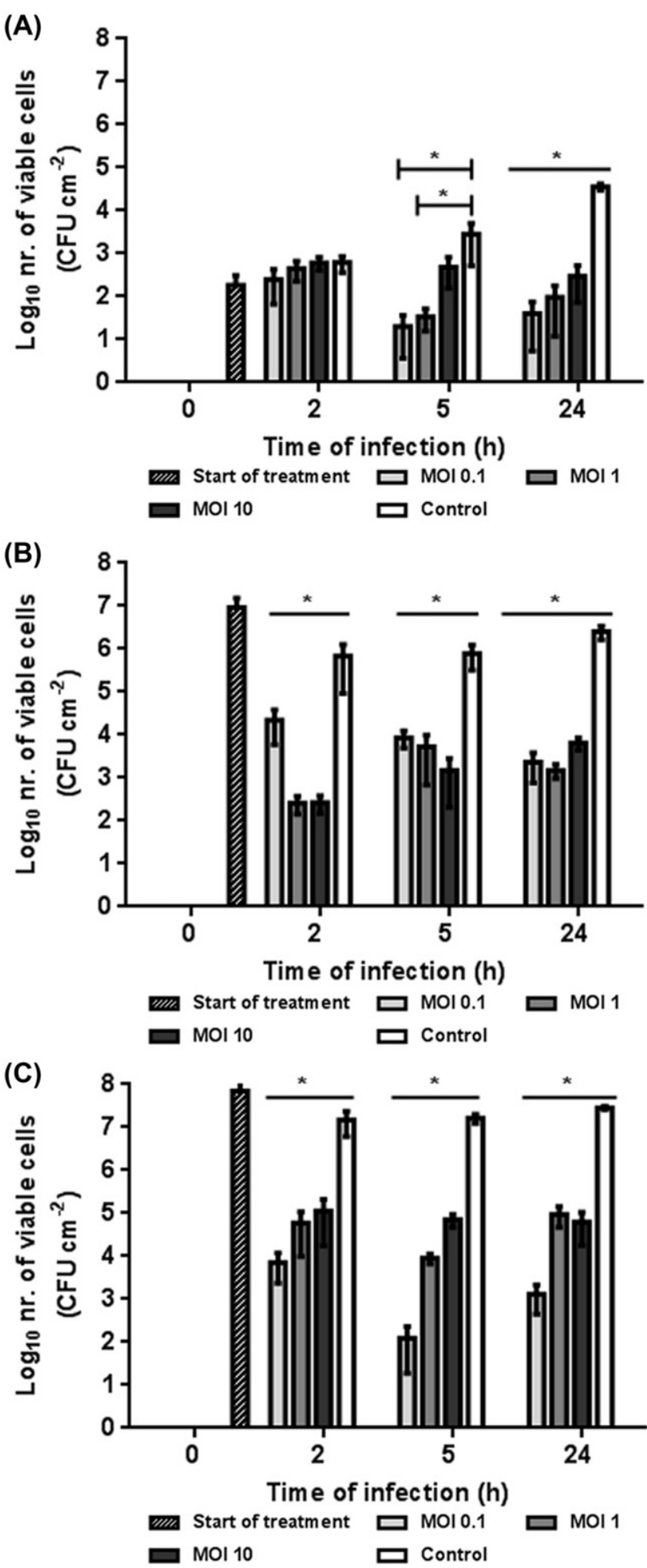

Figure 4. Phage PVP-SE2 control of S. Enteritidis S1400 colonizing 24-well polystyrene plates at $22^{\circ} \mathrm{C}$ for (A) 1 , (B) 24, and (C) $48 \mathrm{~h}$ and phage treatment for 5, 24 and $24 \mathrm{~h}$. * indicate significant differences $(p<0.05)$ between PVP-SE2-treated and control samples.

the results obtained by changing the adhesion kinetics of the bacteria and biofilm formation due to competition from other microorganisms (Tsuno et al. 2002; Stubbendieck and Straight 2016). For instance, the presence of Salmonella or even other bacteria could affect the MOI constants used and affect the adsorption of PVP-SE2. Thus, a range of disinfection approaches were tested (Table S1) and the easiest, fastest and most efficient method to decontaminate the skin samples, when compared to the other tested methods (eg ultrasonic bath, $2 \%$ lactic acid), was adopted as the disinfection procedure. This consisted of applying $96 \%$ ethanol for $30 \mathrm{~s}$ at room temperature. For the phage control experiments on poultry skins, the tested MOIs were of 10 (for comparison purposes with the other two types of surface) and a higher one (MOI 100) (Figure 9A and B). Furthermore, besides this approach, phage pretreatment of skin surfaces to inhibit Salmonella colonization was also assessed (Figure 9C). For this latter experiment, skin samples were pretreated with PVP-SE2 at concentrations of $10^{6}, 10^{7}$ and $10^{8} \mathrm{PFU} \mathrm{ml} \mathrm{m}^{-1}$ before in vitro contaminating the skin samples with Salmonella. Experiments were only carried out at $4{ }^{\circ} \mathrm{C}$ since EFSA and USDA safety recommendations for poultry meat handling do not recommend any type of handling at temperatures above refrigerated temperatures before cooking (EFSA Panel on Biological Hazards (BIOHAZ) 2014; USDA and Food Safety and Inspection Service 2014). In the phage control strategy, in vitro contamination of skins was allowed to proceed for 4 and $24 \mathrm{~h}$. The treatment showed that PVP-SE2 was always able to cause a minor but significant reduction in viable cells and maintained viable Salmonella numbers at steady and lower levels than in the control samples. Maximum reductions were obtained with a MOI of 100 (Figure 9A and B). This suggests that phage PVP-SE2 can be added to poultry meats to inhibit any further growth of Salmonella. In the prevention strategy phages were used to pretreat skin samples (treated using phage concentrations of $10^{4}, 10^{5}$ and $10^{6} \mathrm{PFU} \mathrm{ml}{ }^{-1}$ ) which were post-contaminated with $S$. Enteritidis at $4{ }^{\circ} \mathrm{C}$ (Figure 9C). The highest phage concentration provided the highest inhibition for Salmonella to colonize. Phage PVP-SE2 at $10^{6} \mathrm{PFU} \mathrm{ml} \mathrm{m}^{-1}$ after 5, 24 and $48 \mathrm{~h}$ reduced the levels of Salmonella by 1.4, 1.1 and $1.2 \log \mathrm{CFU}$, respectively.

These results suggest that phage pretreatment of skins, even using low phage concentrations, can decrease the colonization by Salmonella. Furthermore, it is once again important to refer that PVP-SE2 does not lose viability at refrigerated and frozen temperatures as assessed in this work (Figure 3). Thus, pretreatment of skins limits growth of Salmonella once it is taken from refrigerated or frozen temperatures. 
(A)

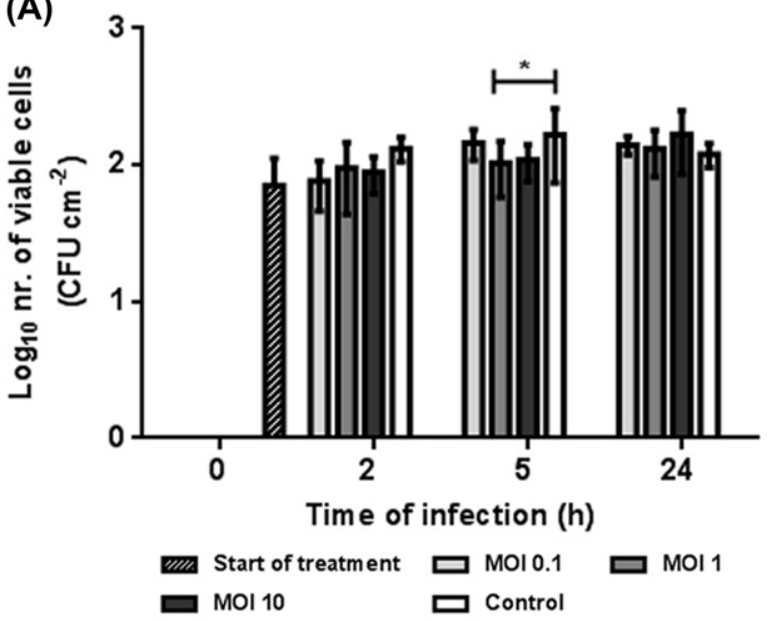

(C)

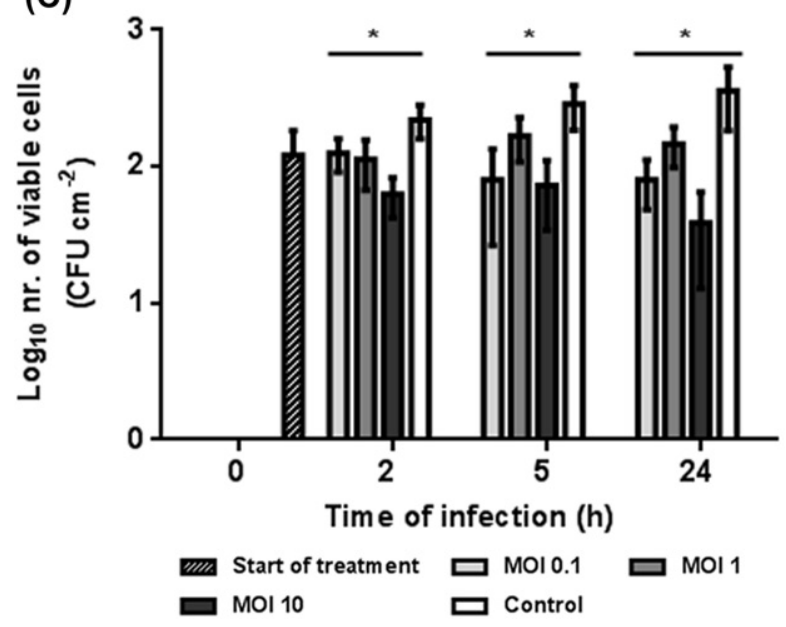

(B)

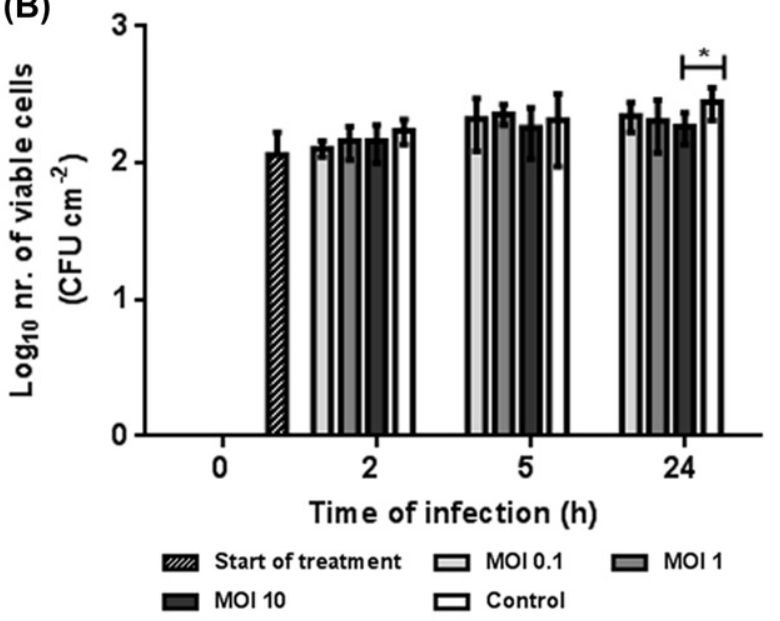

(D)

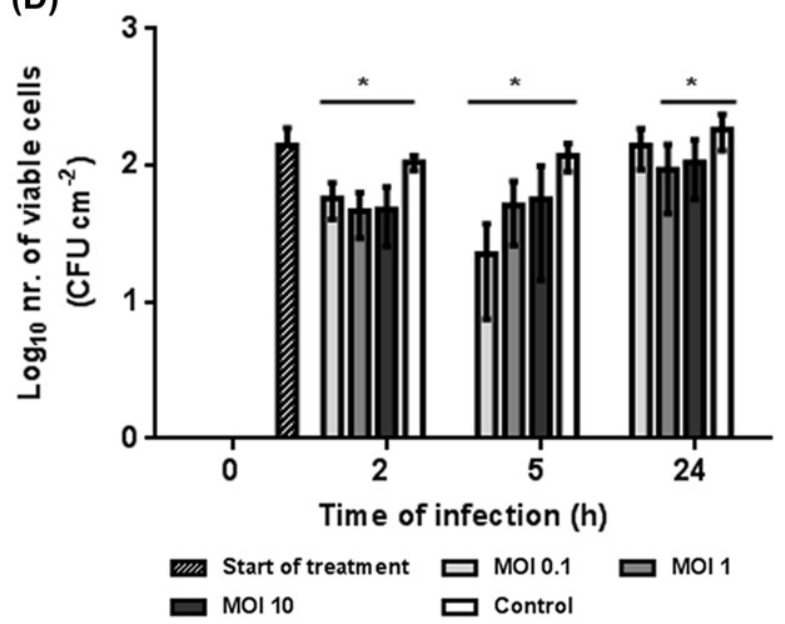

Figure 5. Phage PVP-SE2 control of S. Enteritidis S1400 colonizing 24-well polystyrene plates at $4{ }^{\circ} \mathrm{C}$ for (A) $4 \mathrm{~h}$, (B) $24 \mathrm{~h},(\mathrm{C}) 48$ and (D) $72 \mathrm{~h}$ and phage treatment for 5, 24 and $48 \mathrm{~h}$. * indicate significant differences $(p<0.05)$ between PVP-SE2-treated and control samples.

\section{Susceptibility of resistant colonies}

The susceptibility of several colonies from the polystyrene surfaces that survived the phage treatment were tested against the stock PVP-SE2 solution, phages $\varphi 68$ and $\varphi 135$ (Siphoviridae), and PVP-SE1 (Myoviridae), respectively (Table 1). While the majority of cells remained susceptible to PVP-SE2, several colonies selected from the experiments performed at $22{ }^{\circ} \mathrm{C}$ were no longer susceptible to the other tested phages. At $4{ }^{\circ} \mathrm{C}$, surviving cells remained mostly susceptible to three phages (PVP-SE2, $\varphi 68$, and PVPSE1), although a percentage of these cells had acquired resistance towards phage $\varphi 135$.

Surviving colonies from assays on SS at $4{ }^{\circ} \mathrm{C}$ were susceptible to the phages tested. However, the surviving colonies from experiments at $22^{\circ} \mathrm{C}$ were in general resistant to all the phages tested. The survival of colonies from both the control and the pretreatment experiments on poultry skins were susceptible to the phages tested, which is in accordance with the results presented above at $4{ }^{\circ} \mathrm{C}$ when $\mathrm{SS}$ and polystyrene were used. This suggests that there is no or very limited emergence of resistant phage phenotypes at low temperatures. To assess possible deletions occurring in Salmonella, all phages were plated on LT2 mutant strains, a panel of well-characterized $S$. Typhimurium strains (Figure S1). According to Table 1 and the results showing the ability of phages to form plaques (Figure S1) on these strains, it was hypothesized that the most probable mutation occurring in the majority of the surviving isolates was a deletion of the complete outer core region until the first or second heptose (hep) (Rd1 and Rd2 mutants) in the inner core region.

\section{Discussion}

The term foodborne disease, or more commonly food poisoning, is used to denote gastrointestinal 

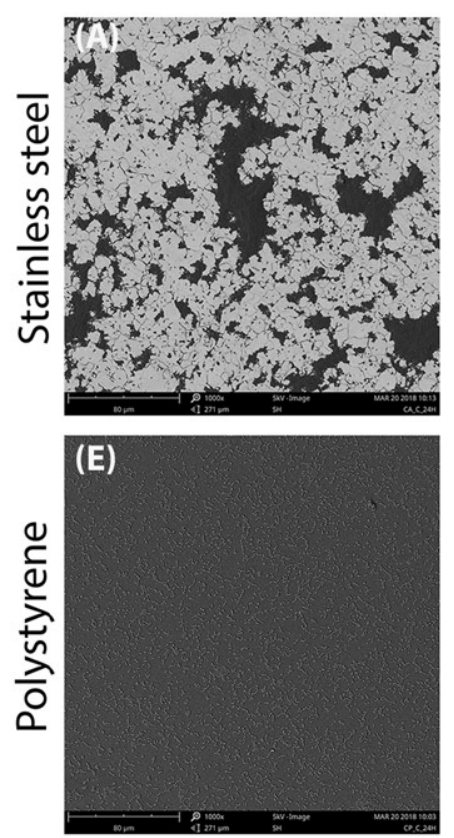
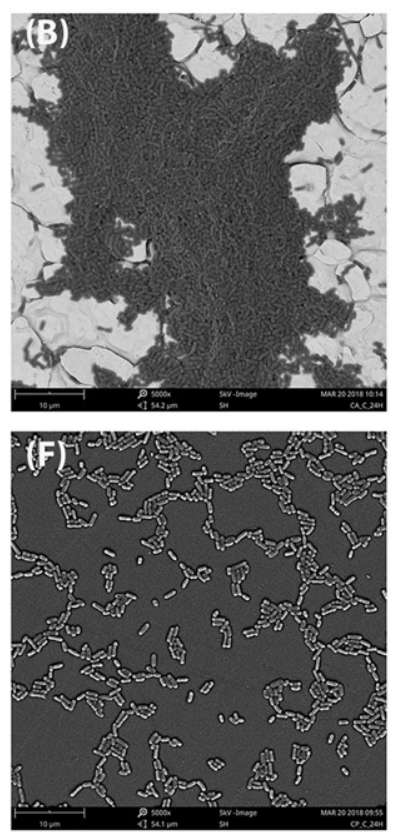

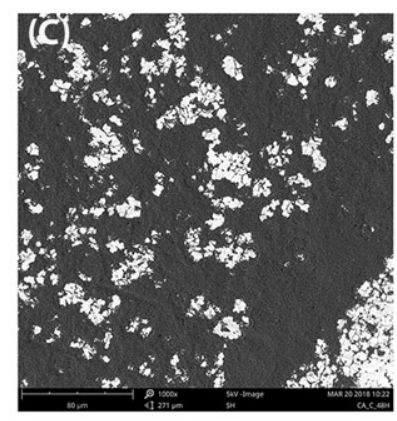

(G)

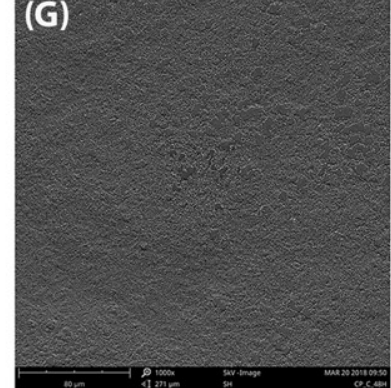

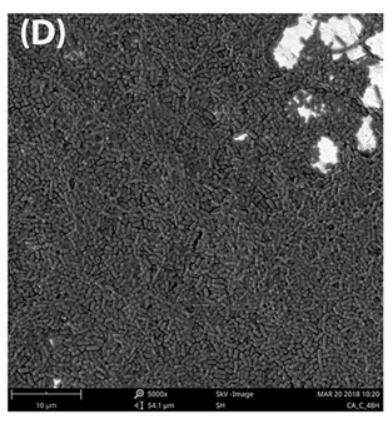

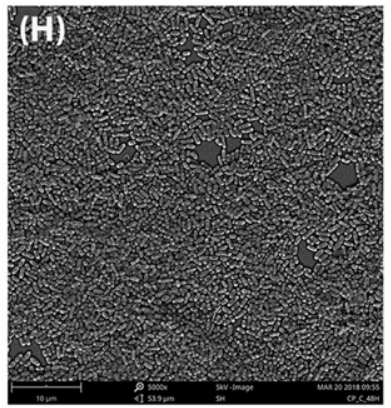

Figure 6. SEM micrographs of $S$. Enteritidis colonization before and after phage application to biofilms formed on SS (A-D) and polystyrene $(\mathrm{E}-\mathrm{H})$ at $22^{\circ} \mathrm{C}$, for $24 \mathrm{~h}(\mathrm{~A}, \mathrm{~B}, \mathrm{E}$ and $\mathrm{F})$ and $48 \mathrm{~h}(\mathrm{C}, \mathrm{D}, \mathrm{G}$ and $\mathrm{H})$.
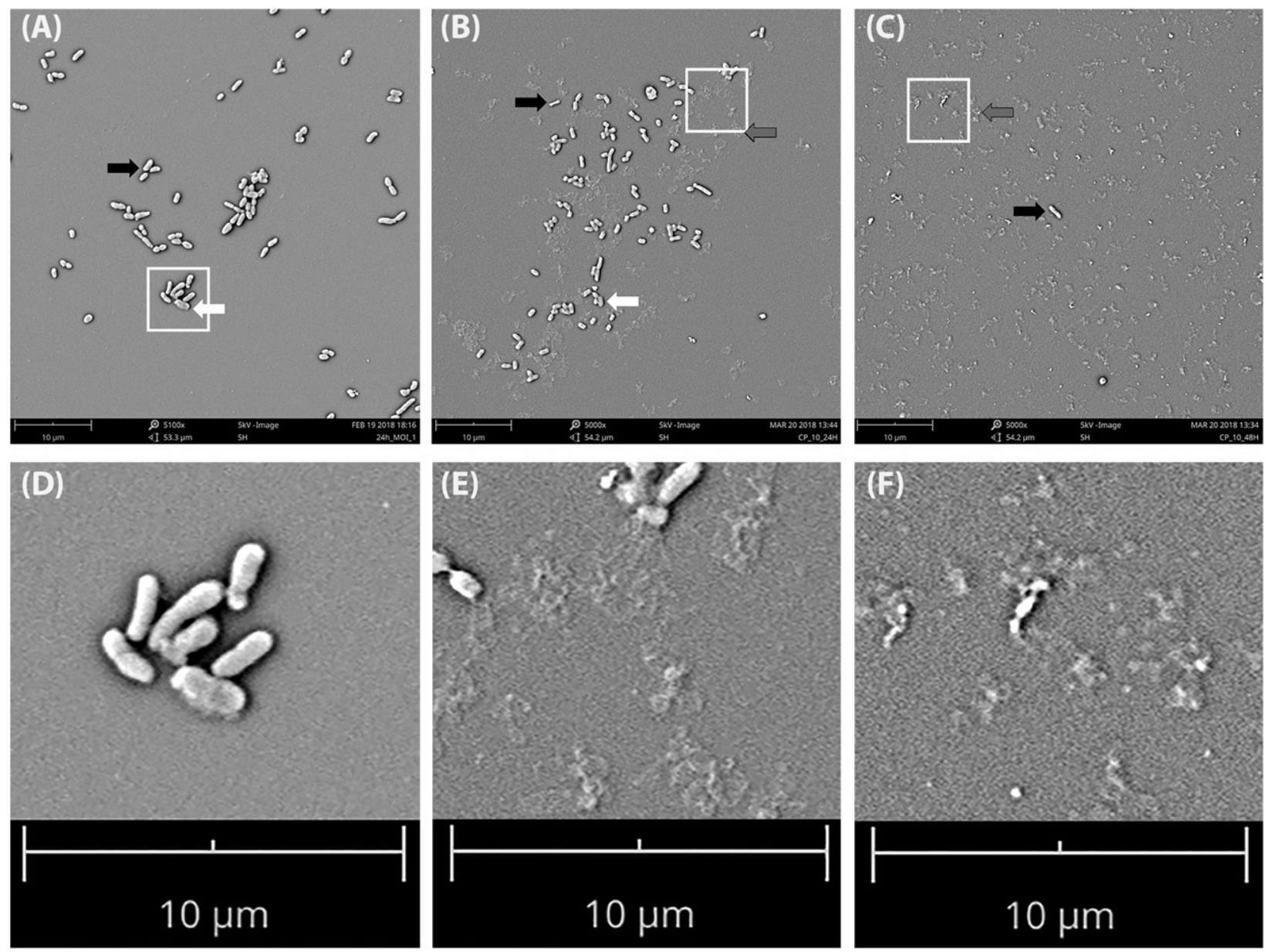

Figure 7. SEM micrographs ( $A, B$ and $C$ ) and their enlargements $(D, E$ and $F$, respectively) after phage application to biofilms formed on polystyrene at $22^{\circ} \mathrm{C}$, showing intact cells (black arrows), damaged cells (white arrows), and cells debris (grey arrows). Magnified areas are indicated by white squares. 
(A)

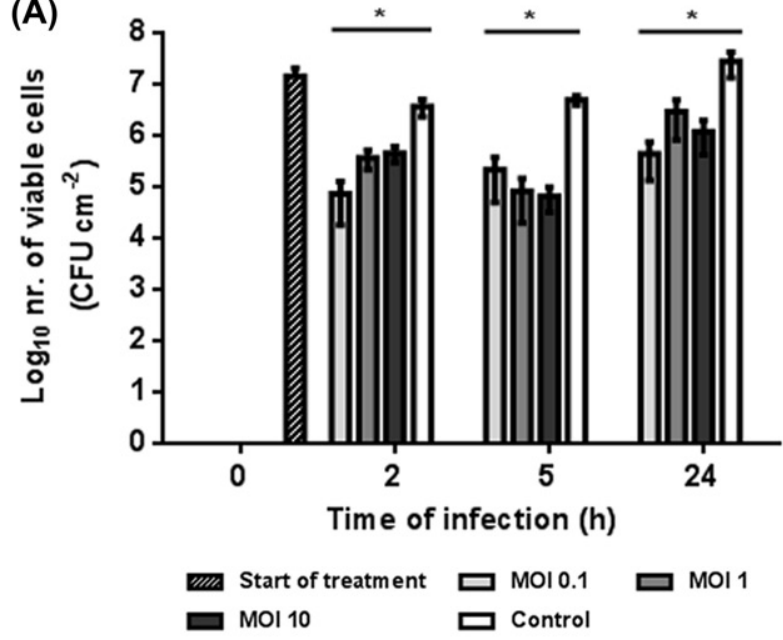

(C)

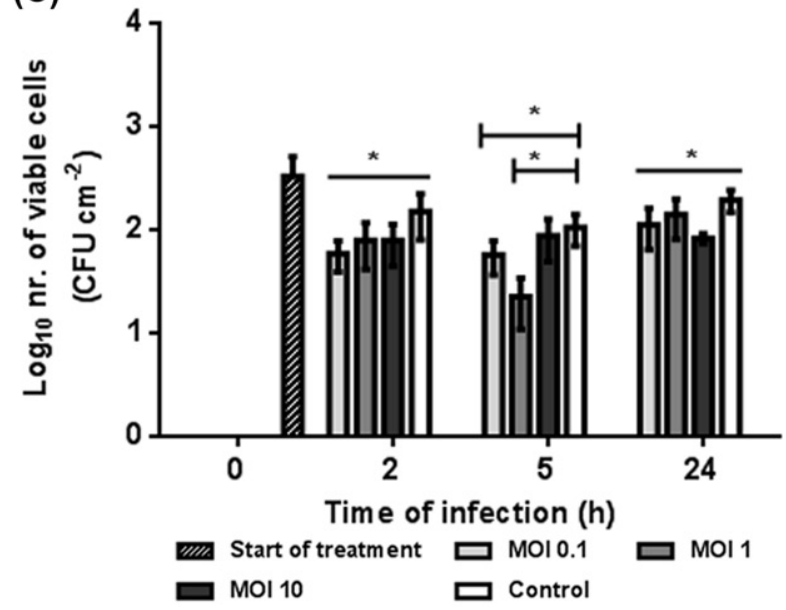

(B)

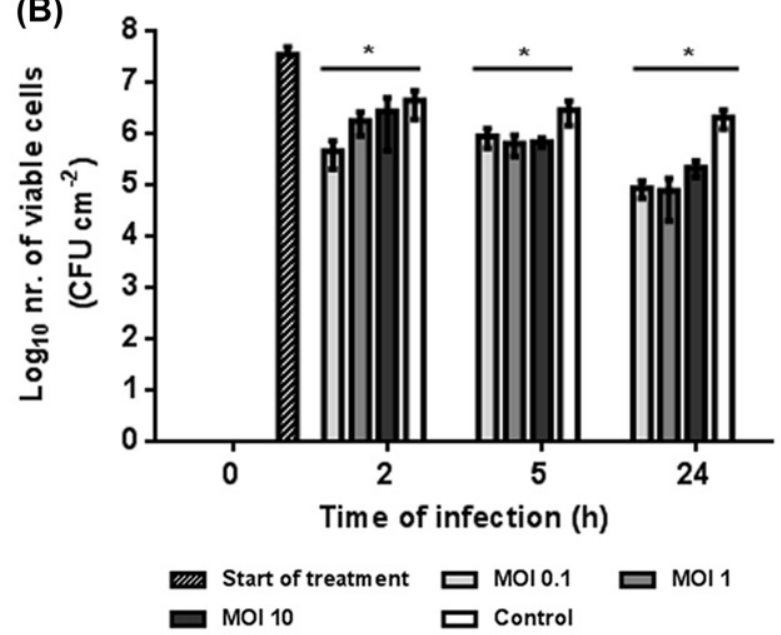

(D)

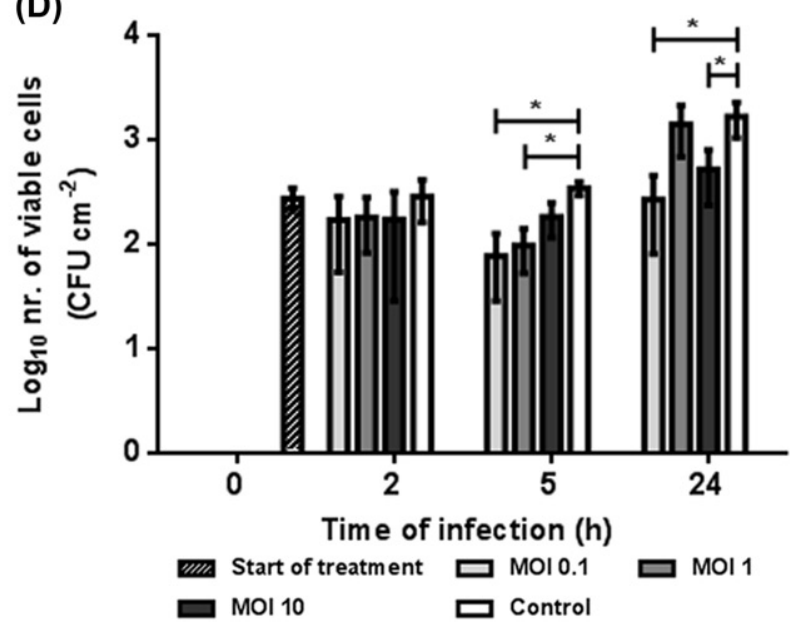

Figure 8. Phage PVP-SE2 control of S. Enteritidis S1400 colonizing SS coupons at $22^{\circ} \mathrm{C}$ (A and B) and $4{ }^{\circ} \mathrm{C}$ (C and D). S. Enteritidis colonization for (A, C) $24 \mathrm{~h},(B, D) 48 \mathrm{~h}$ and phage treatment for 5,24 and $24 \mathrm{~h} . *$ indicate significant differences $(p<0.05)$ between PVP-SE2-treated and control samples.

complications that occur following the consumption of a particular contaminated food or drink. Salmonella is one of the microorganisms most commonly associated with this type of foodborne diseases (CDC 2018a), and its ability to form biofilms on different food working surfaces increases the risk of cross-contamination of food products, particularly poultry products (Grant et al. 2016), and the occurrence of food-outbreaks (Shi and Zhu 2009). A closer look at the surface colonization results obtained in this work show that Salmonella can either: (1) adhere to the different surfaces and not increase in number or (2) adhere and form biofilms. Cell adhesion is mostly observed at refrigerated temperatures and after surface incubation at room temperature for $1 \mathrm{~h}$. This time point $(1 \mathrm{~h})$ at room temperature was chosen to mimic a processing surface that is not immediately disinfected and where, in a few hours, a significant increase in Salmonella numbers was observed (Figure 4). This leads to the need to develop new strategies to control this microorganism if present either in the food product itself or on food processing surfaces. The use of phages as substitutes to other antimicrobials appears to be a good alternative.

In this work, the Salmonella phage PVP-SE2, previously identified as a good candidate for phage biocontrol of Salmonella in poultry meat products (Sillankorva et al. 2010), was characterized and the genomic analysis revealed that the phage does not encode any genes associated with lysogeny or toxin proteins (Table S2). In theory, all virulent phages are able of carrying out generalized transduction, and this would also include phage PVP-SE2. However, this is a rare event since only a minority of new particles $\left(1\right.$ in $\left.10^{4}\right)$ contains bacterial DNA (Griffiths et al. 2000), and thus it is not considered a disadvantage of phage therapy. The potential of this phage to control and inhibit surface colonization by $S$. Enteritidis $\mathrm{S} 1400$ was investigated at refrigerated $\left(4{ }^{\circ} \mathrm{C}\right)$ and room temperature $\left(22^{\circ} \mathrm{C}\right)$. The focus on these two temperatures is related to the presence of Salmonella in the slaughter and processing areas (room 

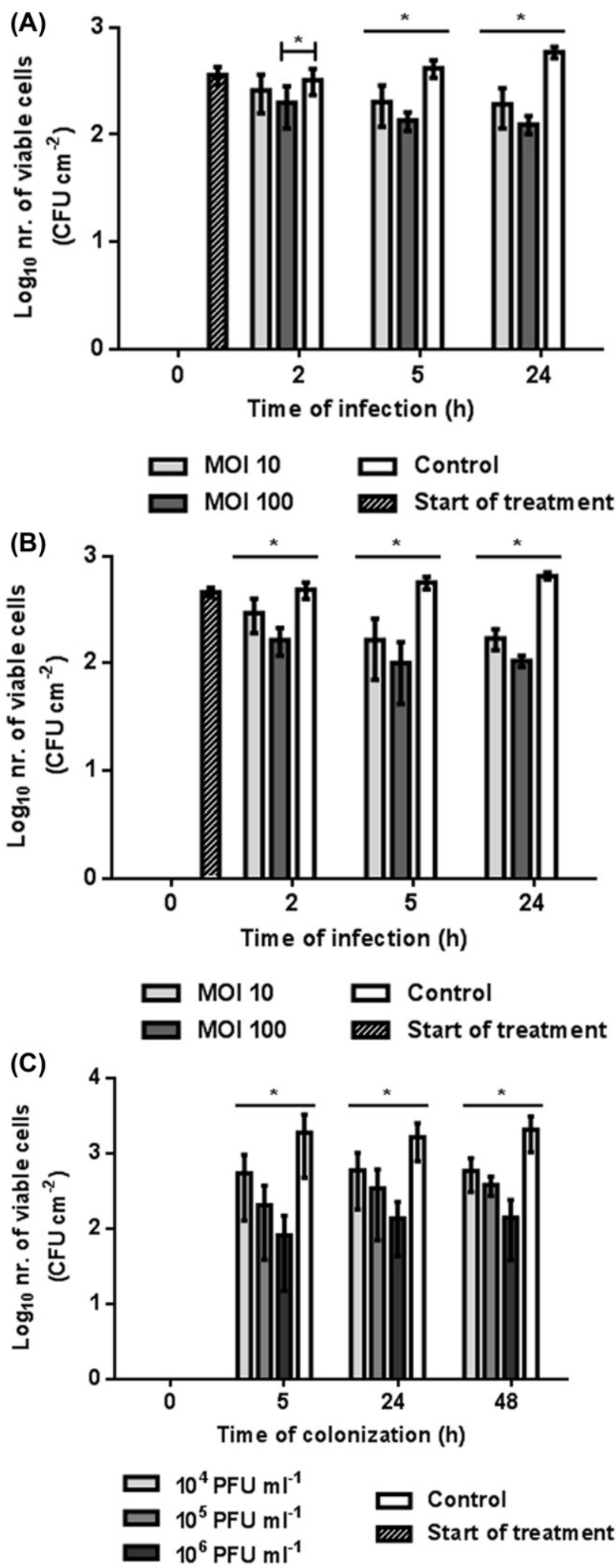

Figure 9. Phage PVP-SE2 control (A and B) and inhibition (C) of $S$. Enteritidis $S 1400$ colonizing poultry skin samples at $4{ }^{\circ} \mathrm{C}$. S. Enteritidis colonization for (A) 4 and (B) $24 \mathrm{~h}$ and phage treatment for 2, 5 and $24 \mathrm{~h}$. (C) Phage pretreatment of skin samples was done with phage concentrations of $10^{4}, 10^{5}$ and $10^{6} \mathrm{PFU} \mathrm{ml} \mathrm{m}^{-1}$. S. Enteritidis colonization for 5, 24 and $48 \mathrm{~h}$. * indicate significant differences $(p<0.05)$ between PVP-SE2treated and control samples.
Table 1. Susceptibility analysis of bacterial colonies that survived infection at $4{ }^{\circ} \mathrm{C}$ on all surfaces and at $22^{\circ} \mathrm{C}$ on polystyrene and stainless steel to phages PVP-SE2, PVP-SE1, $\varphi 68$ and $\varphi 135$.

\begin{tabular}{|c|c|c|c|c|c|c|}
\hline \multirow[b]{2}{*}{ Surface } & \multirow[b]{2}{*}{$\mathrm{T}\left({ }^{\circ} \mathrm{C}\right)$} & \multirow{2}{*}{$\begin{array}{l}\text { MOI or phage } \\
\text { concentration } \\
\text { (log PFU ml } \mathrm{m}^{-1} \text { ) }\end{array}$} & \multicolumn{4}{|c|}{ Phage resistance (\%) } \\
\hline & & & PVP-SE2 & $\varphi 68$ & PVP-SE1 & $\varphi 135$ \\
\hline \multirow[t]{4}{*}{ Polystyrene } & 22 & 0.1 & 8.3 & 25.0 & 25.0 & 25.0 \\
\hline & & 10 & 0.0 & 8.3 & 33.3 & 0.0 \\
\hline & 4 & 0.1 & 0.0 & 0.0 & 0.0 & 16.7 \\
\hline & & 10 & 25.0 & 0.0 & 0.0 & 33.3 \\
\hline \multirow[t]{2}{*}{ Poultry control } & 4 & 10 & 8.3 & 0.0 & 0.0 & 0.0 \\
\hline & & 100 & 25.0 & 8.33 & 0.0 & 0.0 \\
\hline \multirow[t]{2}{*}{$\begin{array}{l}\text { Poultry } \\
\quad \text { pretreatment }\end{array}$} & 4 & 3 & 0.0 & 0.0 & 0.0 & 0.0 \\
\hline & & 5 & 0.0 & 0.0 & 0.0 & 0.0 \\
\hline \multirow[t]{4}{*}{ Stainless steel } & 22 & 0.1 & 100.0 & 100.0 & 0.0 & 33.3 \\
\hline & & 10 & 100.0 & 100.0 & 100.0 & 100.0 \\
\hline & 4 & 0.1 & 0.0 & 0.0 & 0.0 & 0.0 \\
\hline & & 10 & 0.0 & 0.0 & 0.0 & 0.0 \\
\hline
\end{tabular}

temperature), as well as at lower temperatures $\left(\approx 4^{\circ} \mathrm{C}\right)$ where the products are stored. To test the ability of phage PVP-SE2 to control Salmonella, three surfaces were used: polystyrene and SS, since they are commonly used in food processing plants (Steenackers et al. 2012), and poultry skins.

The treatment with phage PVP-SE2 of adhered and biofilm cells grown in both polystyrene and SS was shown to be more effective at $22^{\circ} \mathrm{C}$ than at refrigerated temperatures. This result was expected owing to the closer optimal growth conditions in which Salmonella maintains a quite active metabolism when compared to $4{ }^{\circ} \mathrm{C}$. It is generally accepted that cell growth and temperature conditions have a major effect on phage replication. For instance, the replication of coliphage FRNA at lower than optimal cell growth temperature conditions is slower and can even cease because of the lower expression of $\mathrm{F}$ pili and adsorption inhibition (Knolle and Orskov 1967; Woody and Cliver 1995). Similar results have also been reported for phages of Listeria (Tokman et al. 2016) and Pseudomonas fluorescens (Sillankorva et al. 2004) where incubation at refrigeration temperatures resulted in an increase in the latent period, a reduction in phage burst size and overall lower killing efficacy.

Increasing the incubation period of Salmonella at $22^{\circ} \mathrm{C}$ in polystyrene and SS led to approximately similar viable cell counts at the tested biofilm formation periods $\left(\sim 7 \log \mathrm{CFU} \mathrm{cm} \mathrm{cm}^{-2}\right.$ after $24 \mathrm{~h}$ and closer to $8 \log \mathrm{CFU} \mathrm{cm} \mathrm{cm}^{-2}$ after $48 \mathrm{~h}$ ) (Figures 4 and 7 ). Phage treatment of Salmonella was highly influenced by the type of surface the bacteria were attached to. Greater reductions were always observed for cells attached to polystyrene ( 3 to $5 \log \mathrm{CFU} \mathrm{cm}{ }^{-2}$ ) rather

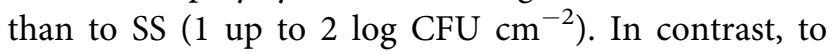


these results, it has been reported that biofilms grown on SS are more susceptible to sanitizers compared to those on Teflon surfaces (Pan et al. 2006; Poimenidou et al. 2016). According to these authors, polymers are more prone to chemical and mechanical damage and therefore provide increased shelter for bacteria. In the present study, the differences in phage efficacy might be explained by the different biofilm structures formed on both surfaces. Polystyrene is a hydrophobic smooth surface and therefore cells have more difficulty in attaching, forming thin and small clusters of cells spread on the surface (Figure 6E-H). Adhesion to SS is more favorable due to its roughness and therefore cells form thick layers covering all the surface leading to a denser structure which is more difficult to penetrate by phages (Figure 6A-D).

In the experiments there was never a straight correlation between the MOI applied and the cell lysis caused. For instance, in the experiments with polystyrene, the best cell lysis results were obtained with a MOI of 0.1, although it might be expected that the use of a MOI of 1.0 or higher would lead to higher viable cell reductions. For SS the results for the highest lysis efficiencies were far more inconsistent. This may be due to the roughness of the SS coupons since it potentiates the retention of the biofilm to the SS and also protects it from shear forces (Taylor et al. 1998; Nejadnik et al. 2008). Furthermore, deposition/ adhesion of phages occurs to varied abiotic surfaces, such as SS (Sillankorva et al. 2008b), and has been shown to increase, for instance for F-specific RNA phages, with the increase in the degree of hydrophobicity and/or roughness (Dika et al. 2013). This nonspecific binding may explain the lower effectiveness of phage on SS where, hypothetically, the phages deposit in higher amounts and consequently not all phages are free to complete infection cycles. Previous work suggests that higher phage doses lead to reduced lysing efficacy due to the mechanism of lysis inhibition, which happens when cell density reaches concentrations of $4 \times 10^{7} \mathrm{CFU} \mathrm{m}{ }^{-1}$ (Abedon 1990). This observation could explain the results obtained with polystyrene. However, this phenomenon should not be surface dependent, as observed in this experiment. Overall, these results suggest that there is not a universal phage MOI strategy for biofilm control, as it is dependent on the substrata chosen for the experiments, the 3-D biofilm architecture and the level of protection that the extracellular polymeric matrix confers.

In general, it was observed that phage application for $2 \mathrm{~h}$ was not enough to substantially reduce the number of viable cells, indicating that for a rapid surface sanitation stronger antimicrobials that act immediately are needed. Nevertheless, taking into account the results, phage PVP-SE2 seems to be a very good control agent of 24 and 48 -h old biofilms of $S$. Enteritidis at $22^{\circ} \mathrm{C}$. Therefore, for a better antimicrobial effect desirable for short periods, phages could be mixed with other agents for a higher and possibly synergistic action against foodborne pathogens. For instance, phages added together with chlorine, a disinfectant commonly used in the food industry, acted synergistically in the control and removal of Pseudomonas aeruginosa biofilms (Zhang and $\mathrm{Hu}$ 2013). Chibeu et al. (2013) demonstrated that the combination of the bacteriophage preparation Listex $^{\mathrm{TM}} \mathrm{P} 100$ with the chemical compounds potassium lactate and sodium diacetate resulted in an improvement in their action against bacteria present on the surface of Ready to eat (RTE) roast beef and cooked turkey when compared with each agent alone (Chibeu et al. 2013). Also, Sukumaran et al. (2015) showed that the combined or sequential application of the bacteriophage preparation SalmoFresh ${ }^{\mathrm{TM}}$ with lauric arginate or cetylpyridinum chloride was beneficial in reducing Salmonella on chicken meat and chicken skin.

If the specific action of phage PVP-SE2 is compared with other phages, obviously tested using a different host, some conclusions can be drawn. For instance, in one study, $S$. Enteritidis biofilms grown for four days $\left(\approx 10^{6} \mathrm{CFU} \mathrm{ml}{ }^{-1}\right)$ at $25^{\circ} \mathrm{C}$ on SS coupons were challenged with a mixture of five phages at a MOI of 10 for 60 min (Ferreira et al. 2011). In this case, reductions lower than 0.4 logs were obtained. In another study, a group of $S$. enterica strains was grown on SS coupons and a pool of phages was applied for a period of eight days at room temperature (Gong and Jiang 2017). Although after phage treatment for seven days $S$. enterica biofilms suffered high inhibition, after treatment for one day the number of viable cells dropped less than $1 \log$. Both these results present similar or lower reduction values than those obtained with PVP-SE2.

The ability of PVP-SE2 as a control agent of Salmonella in artificially contaminated chicken skin samples was tested at $4{ }^{\circ} \mathrm{C}$ with MOIs of 10 and 100 . The higher titer was more efficient with an increase in the number of $S$. Enteritidis cells killed if the treatment period was increased. Similar and higher reductions, at $4{ }^{\circ} \mathrm{C}$, to those obtained with PVP-SE2 have been reported for $S$. Enteritidis on poultry skins (Goode et al. 2003; Hagens 2015).

The use of PVP-SE2 to prevent contamination of poultry meat showed that the PVP-SE2 phage 
previously added to the chicken skin samples can decrease significantly the number of viable cells compared to the control samples. Higher phage concentrations used in the pretreatment of skins resulted in greater reductions in bacterial numbers for all time periods of skin colonization assessed (1.4, 1.1 and 1.2 $\log \mathrm{CFU} \mathrm{cm} \mathrm{cm}^{-2}$ reductions at 5, 24 and $48 \mathrm{~h}$, respectively). This result is a good indication that PVP-SE2 phage can be used as an agent to prevent contamination of poultry meat at refrigerated temperatures.

Even though the results at $4{ }^{\circ} \mathrm{C}$ from the SS and polystyrene experiments provided only a slight antimicrobial effect, if the samples are taken from refrigerated temperatures to room temperatures (eg periods from store to home) there is an evident advantage of phages to limit the growth of Salmonella present in foods. Also, strategically, phage survival at $-18^{\circ} \mathrm{C}$ was tested. The reason for this is that poultry meat is considered fresh when stored at $4{ }^{\circ} \mathrm{C}$ up to three days, otherwise it is stored at $-18{ }^{\circ} \mathrm{C}$ (USDA and Food Safety and Inspection Service 2015). The results at this temperature show that phage PVP-SE2 maintained its viability on the surface of chicken skins for 10 days when kept either under fresh or frozen conditions. Previous studies have shown that tailed phages can remain viable at refrigerated temperatures even for 10-12 years (Ackermann et al. 2004). However, most phages tend not to remain stable at $-20^{\circ} \mathrm{C}$ and therefore lose viability, which is not the case for phage PVP-SE2. For instance, several E. coli phages were submitted to storage at freezing temperatures and were shown to be stable only for one day (Litt and Jaroni 2017). After this, the authors observed an accentuated reduction of phage titers (4.0-6.3 logs PFU ml ${ }^{-1}$ ). This loss in titer is known to be due to the formation of ice crystals (Warren and Hatch 1969; Gould 1999). Although tailed phages tend to maintain viability at $4{ }^{\circ} \mathrm{C}$, some phages are highly sensitive, such as phage Stx2, from E. coli, that was shown to substantially reduce in viability after only one day (Rode et al. 2011).

Bacteriophage hosts have developed several resistance mechanisms to survive these viruses (Labrie et al. 2010). In terms of the resistance of $S$. Enteritidis to phages, the main mechanism that this bacterium adopts is to lose the core O-polysaccharide (Santander and Robeson 2007). In this work the susceptibility of cells from the different experiments that had survived phage treatment were tested and four different phages (Table 1) were chosen. Three of these phages (PVPSE2, $\varphi 68$ and $\varphi 135)$ had been shown previously to be highly similar in genome size that varied between 32 and $38 \mathrm{~kb}$ (Sillankorva et al. 2010). As expected, higher numbers of resistant colonies emerged at $22^{\circ} \mathrm{C}$ than at $4{ }^{\circ} \mathrm{C}$, with percentages varying between 0 and $33.3 \%$ in cells recovered from biofilms formed on polystyrene and $0-100 \%$ in cells from SS surfaces, respectively. Since biofilms formed on SS were thicker compared to those formed on polystyrene, cells will be subjected to more stress, and the existence of cellular metabolites and oxygen reactive species surrounding biofilm cells may induce mutations at a higher rate due to the diffusional limitations (Pires et al. 2017). At $4{ }^{\circ} \mathrm{C}$, most of the surviving cells recovered from polystyrene and SS surfaces as well as from poultry skins (control and pretreatment experiments) were susceptible to all four phages. Also, to assess the LPS chain mutations that led to negative results (no phage plaques formed), the four phages were plated on LT2 mutant strains, which have mutations in different regions of their LPS chain (Figure S1). All phages were infective towards the smooth wild type $S$. Typhimurium strain LT2 and the Re mutant strains. None of the tested phages produced plaques in LT2 mutants Rd1 and Rd2, which suggests that these surviving isolates are devoid of the necessary oligosaccharide component for phage adsorption. However, more surviving colonies should be assessed and their LPS characteristics analyzed by sodium dodecyl sulfate (SDS) polyacrylamide gel electrophoresis to confirm the suspected deletions.

In conclusion, it has been demonstrated that phage PVP-SE2 has the ability to act as a control agent of $S$. Enteritidis biofilm and adhered cells on different surfaces, viz. polystyrene, SS and poultry skin, at 4 and $22^{\circ} \mathrm{C}$. Furthermore, this phage showed promising results when used for the prevention of contamination of poultry skin at $4{ }^{\circ} \mathrm{C}$. Taking all this information into account and the fact that the PVP-SE2 genome does not contain genes that encode for bacterial toxins nor lysogeny related genes, it can be concluded that phage PVPSE2 is a good candidate for safe use in the control/ prevention of $S$. Enteritidis contamination of food related surfaces.

\section{Disclosure statement}

No potential conflict of interest was reported by the authors.

\section{Funding}

Catarina Milho acknowledges the Portuguese Foundation for Science and Technology (FCT) grant [SFRH/BD/94434/ 2013]. Sanna Sillankorva is an Investigador FCT [IF/01413/ 2013]. This study was supported by the Portuguese 
Foundation for Science and Technology (FCT) under the scope of the strategic funding of UID/BIO/04469/2013 unit and COMPETE 2020 [POCI-01-0145-FEDER-006684] and BioTecNorte operation [NORTE-01-0145-FEDER-000004] funded by the European Regional Development Fund under the scope of Norte2020 - Programa Operacional Regional do Norte and the Project RECI/BBB-EBI/0179/2012 [FCOMP-01-0124-FEDER-027462].

\section{ORCID}

Catarina Milho (D) https://orcid.org/0000-0002-4176-765X Maria Daniela Silva (D https://orcid.org/0000-0003-

2495-6026

Luís Melo (D) https://orcid.org/0000-0002-6865-6044

Sílvio Santos (iD http://orcid.org/0000-0003-0801-8080

Joana Azeredo (D) http://orcid.org/0000-0002-5180-7133

Sanna Sillankorva (D) http://orcid.org/0000-0002-8408-8550

\section{References}

Abedon ST. 1990. Selection for lysis inhibition in bacteriophage. J Theor Biol. 146:501-511. doi: 10.1016/S00225193(05)80375-3.

Ackermann HW. 2009. Basic phage electron microscopy. Methods Mol Biol. 501:113-126. doi: 10.1007/978-160327-164-6_12.

Ackermann HW, Tremblay D, Moineau S. 2004. Long-term bacteriophage preservation. WFCC Newslet, 38:35-40.

Adams M. 1959. Bacteriophages. New York, NY: Interscience Publishers, Inc.

Altschul SF, et al. 1990. Basic local alignment search tool. J Mol Biol. 215:403-410. doi: 10.1016/S0022-2836(05)80360-2.

Altschul SF, et al. 1997. Gapped BLAST and PSI-BLAST: a new generation of protein database search programs. Nucleic Acids Res. 25:3389-3402. doi: 10.1093/nar/ 25.17.3389.

Ashelford KE, Day MJ, Fry JC. 2003. Elevated abundance of bacteriophage infecting bacteria in soil. Appl Environ Microbiol. 69:285-289. doi: 10.1128/AEM.69.1.285289.2003.

Atterbury RJ, Connerton PL, Dodd CE, Rees CE, Connerton IF. 2003. Application of host-specific bacteriophages to the surface of chicken skin leads to a reduction in recovery of Campylobacter jejuni. Appl Environ Microbiol. 69:6302-6306. doi: 10.1128/AEM.69.10.63026306.2003.

Aziz RK, Bartels D, Best AA, DeJongh M, Disz T, Edwards RA, Formsma K, Gerdes S, Glass EM, Kubal M, et al. 2008. The RAST Server: rapid annotations using subsystems technology. BMC Genom. 9:75. doi: 10.1186/14712164-9-75.

Carlton RM, Noordman WH, Biswas B, de Meester ED, Loessner MJ. 2005. Bacteriophage P100 for control of Listeria monocytogenes in foods: genome sequence, bioinformatic analyses, oral toxicity study, and application. Regul Toxicol Pharmacol 43:301-312. doi: 10.1016/ j.yrtph.2005.08.005.

Centers for Disease Control and Prevention (CDC). 2018a. Salmonella - information for healthcare professionals and laboratories. [accessed: 2018 Mar 9] http://www.cdc.gov/ salmonella/general/technical.html.

Centers for Disease Control and Prevention (CDC). 2018b. Salmonella - reports of selected Salmonella outbreak investigations. [accessed: 2018 Feb 12]. https://www.cdc.gov/salmonella/outbreaks.html

Chibeu A, Agius L, Gao A, Sabour PM, Kropinski AM, Balamurugan S. 2013. Efficacy of bacteriophage LISTEX $^{\mathrm{TM}}$ P100 combined with chemical antimicrobials in reducing Listeria monocytogenes in cooked turkey and roast beef. Int J Food Microbiol. 167:208-214.

Clark JR, March JB. 2006. Bacteriophages and biotechnology: vaccines, gene therapy and antibacterials. Trends Biotechnol. 24:212-218. doi:10.1016/j.tibtech.2006.03.003.

Dika C, Ly-Chatain MH, Francius G, Duval JFL, Gantzer C. 2013. Non-DLVO adhesion of F-specific RNA bacteriophages to abiotic surfaces: importance of surface roughness, hydrophobic and electrostatic interactions. Colloids Surf A. 435:178-187. doi: 10.1016/j.colsurfa.2013.02.045.

DuPont HL. 2007. The growing threat of foodborne bacterial enteropathogens of animal origin. Clin Infect Dis. 45:1353-1361. doi: 10.1086/522662.

[EFSA] European Food Safety Authority, Panel on Biological Hazards (BIOHAZ). 2014. Scientific Opinion on the public health risks related to the maintenance of the cold chain during storage and transport of meat. Part 1 (meat of domestic ungulates). EFSA Journal. 12:1-81. doi: 10.2903/j.efsa.2014.3601.

European Food Safety Authority and European Centre for Disease Prevention and Control. 2016. The European Union summary report on trends and sources of zoonoses, zoonotic agents and food-borne outbreaks in 2015. EFSA Journal. 14:4634. doi: 10.2903/j.efsa.2016.4634.

FDA and Department of Health and Human Services. 2006. Food additives permitted for direct addition to food for human consumption; bacteriophage preparation. Fed Regist. 71:47729-47732.

Ferreira, AA, Mendonça RCS, Hungaro HM, Carvalho MM, Pereira JAM. 2011. Bacteriophages actions on Salmonella Enteritidis biofilm. In: Science and technology against microbial pathogens: research, development and evaluation. Valladolid: World Scientific. p. 135-139. doi: 10.1142/9789814354868_0026.

Finn RD, Bateman A, Clements J, Coggill P, Eberhardt RY, Eddy SR, Heger A, Hetherington K, Holm L, Mistry J et al. 2014. Pfam: the protein families database. Nucleic Acids Res. 42:D222-D230. doi: 10.1093/nar/gkt1223.

Finn RD, Attwood TK, Babbitt PC, Bateman A, Bork P, Bridge AJ, Chang HY, Dosztányi Z, El-Gebali S, Fraser $\mathrm{M}$ et al. 2017. InterPro in 2017-beyond protein family and domain annotations. Nucleic Acids Res. 45:D190-D199. doi: 10.1093/nar/gkw1107.

Finstad S, O’Bryan CA, Marcy JA, Crandall PG, Ricke SC. 2012. Salmonella and broiler processing in the United States: relationship to foodborne salmonellosis. Food Res Int. 45:789-794. doi: 10.1016/j.foodres.2011.03.057.

Gong C, Jiang X. 2017. Application of bacteriophages to reduce Salmonella attachment and biofilms on hard surfaces. Poult Sci. 96:1838-1848. doi: 10.3382/ps/pew463.

Goode D, Allen VM, Barrow PA. 2003. Reduction of experimental Salmonella and Campylobacter contamination of chicken skin by application of lytic bacteriophages. Appl 
Environ Microbiol. 69:5032-5036. doi: 10.1128/AEM.69.8. 5032-5036.2003.

Gould E. 1999. Methods for long-term virus preservation. Mol Biotechnol. 13:57-66. doi: 10.1385/MB:13:1:57.

Grant A, Hashem F, Parveen S. 2016. Salmonella and Campylobacter: antimicrobial resistance and bacteriophage control in poultry. Food Microbiol. 53:104-109. doi: 10.1016/j.fm.2015.09.008.

Griffiths AJF, Miller JH, Suzuki DT, Lewontin RC, Gelbart WM. 2000. An introduction to genetic analysis. 7th edn. New York, NY: W.H.Freeman \& Co Ltd.

Gutiérrez D, Rodríguez-Rubio L, Martínez B, Rodríguez A, García P. 2016. Bacteriophages as weapons against bacterial biofilms in the food industry. Front Microbiol. 7:825. doi: $10.3389 /$ fmicb.2016.00825.

Hagens S. 2015. Salmonelex ${ }^{\text {TM }}$ GRAS Notification. Wageningen: Micreos B.V.

Hanlon GW. 2007. Bacteriophages: an appraisal of their role in the treatment of bacterial infections. Int J Antimicrob Agents. 30:118-128. doi: 10.1016/j.ijantimicag.2007.04.006.

Helke KL, McCrackin MA, Galloway AM, Poole AZ, Salgado CD, Marriott BP. 2017. Effects of antimicrobial use in agricultural animals on drug-resistant foodborne salmonellosis in humans: a systematic literature review. Crit Rev Food Sci Nutr. 53:472-488. doi: 10.1080/ 10408398.2016.1230088.

Higgins JP, Higgins SE, Guenther KL, Huff W, Donoghue AM, Donoghue DJ, Hargis BM. 2005. Use of a specific bacteriophage treatment to reduce Salmonella in poultry products. Poult Sci. 84:1141-1145. doi: 10.1093/ps/84.7.1141.

Joseph B, Otta SK, Karunasagar I, Karunasagar I. 2001. Biofilm formation by Salmonella spp. on food contact surfaces and their sensitivity to sanitizers. Int J Food Microbiol. 64:367-372. doi: 10.1016/S0168-1605(00)00466-9.

Käll L, Krogh A, Sonnhammer ELL. 2004. A combined transmembrane topology and signal peptide prediction method. J Mol Biol. 338:1027-1036. doi: 10.1016/j.jmb.2004.03.016.

Käll L, Sonnhammer ELL. 2002. Reliability of transmembrane predictions in whole-genome data. FEBS Lett. 532:415-418. doi: 10.1016/S0014-5793(02)03730-4.

Klucar L, Stano M, Hajduk M. 2009. PhiSITE: Database of gene regulation in bacteriophages. Nucleic Acids Res. 38(Database issue):D366-D370. doi: 10.1093/nar/gkp911.

Knolle P, Orskov I. 1967. The identity of the $\mathrm{f}+$ antigen and the cellular receptor for the RNA phage fr. Mol Gen Genet. 99:109-114. doi: 10.1007/BF00306463.

Labrie SJ, Samson JE, Moineau S. 2010. Bacteriophage resistance mechanisms. Nat Rev Microbiol. 8:317-327. doi: $10.1038 /$ nrmicro2315.

Litt PK, Jaroni D. 2017. Isolation and physiomorphological characterization of Escherichia coli O157:H7-infecting bacteriophages recovered from beef cattle operations. Int J Microbiol. 2017:7013236. doi: 10.1155/2017/7013236.

Mead G, Lammerding AM, Cox N, Doyle MP, Humbert F, Kulikovskiy A, Panin A, do Nascimento VP, Wierup M; Salmonella on Raw Poultry Writing Committee. 2010. Scientific and technical factors affecting the setting of Salmonella criteria for raw poultry: a global perspective. J Food Pro. 73:1566-1590. doi: 10.4315/0362-028X-73.8.1566.

Melo LD, Sillankorva S, Ackermann HW, Kropinski AM, Azeredo J, Cerca N. 2014. Isolation and characterization of a new Staphylococcus epidermidis broad-spectrum bacteriophage. J Gen Virol. 95:506-515. doi: 10.1099/ vir.0.060590-0.

Moons P, Faster D, Aertsen A. 2013. Lysogenic conversion and phage resistance development in phage exposed Escherichia coli biofilms. Viruses. 5:150-161. doi: 10.3390/v5010150.

Naville M, Ghuillot-Gaudeffroy A, Marchais A, Gautheret D. 2011. ARNold: a web tool for the prediction of Rhoindependent transcription terminators. RNA Biol. 8:11-13. doi: 10.4161/rna.8.1.13346.

Nejadnik MR, van der Mei HC, Busscher HJ, Norde W. 2008. Determination of the shear force at the balance between bacterial attachment and detachment in weak-adherence systems, using a flow displacement chamber. Appl Environ Microbiol. 74:916-919. doi: 10.1128/AEM.01557-07.

Pan Y, Breidt FJ, Kathariou S. 2006. Resistance of Listeria monocytogenes biofilms to sanitizing agents in a simulated food processing environment. Appl Environ Microbiol. 72:7711-7717. doi: 10.1128/AEM.01065-06.

Pires DP, Dötsch A, Anderson EM, Hao Y, Khursigara CM, Lam JS, Sillankorva S, Azeredo J. 2017. A genotypic analysis of five $P$. aeruginosa strains after biofilm infection by phages targeting different cell surface receptors. Front Microbiol. 8:1229. doi:10.3389/fmicb.2017.01229.

Poimenidou SV, Chrysadakou M, Tzakoniati A, Bikouli VC, Nychas GJ, Skandamis PN. 2016. Variability of Listeria monocytogenes strains in biofilm formation on stainless steel and polystyrene materials and resistance to peracetic acid and quaternary ammonium compounds. Int J Food Microbiol. 237:164-171. doi: 10.1016/j.ijfoodmicro.2016.08.029.

Rode TM, Axelsson L, Granum PE, Heir E, Holck A, L'abéeLund TM. 2011. High stability of Stx 2 phage in food and under food-processing conditions. Appl Environ Microbiol. 77:5336-5341. doi: 10.1128/AEM.00180-11.

Santander J, Robeson J. 2007. Phage-resistance of Salmonella enterica serovar Enteritidis and pathogenesis in Caenorhabditis elegans is mediated by the lipopolysaccharide. Electron J Biotechnol. 10:627-632. doi: 10.2225/ vol10-issue4-fulltext-14.

Schattner P, Brooks AN, Lowe TM. 2005. The tRNAscanSE, snoscan and snoGPS web servers for the detection of tRNAs and snoRNAs. Nucleic Acids Res. W686-W689. doi: 10.1093/nar/gki366.

Shi X, Zhu X. 2009. Biofilm formation and food safety in food industries. Trends Food Sci Technol. 20:407-413. doi: 10.1016/j.tifs.2009.01.054.

Sillankorva S, Oliveira R, Vieira MJ, Sutherland I, Azeredo J. 2004. Pseudomonas fluorescens infection by bacteriophage DS1: the influence of temperature, host growth phase and media. FEMS Microbiol Lett. 241:13-20. doi: 10.1016/j.femsle.2004.06.058.

Sillankorva S, Pleteneva E, Shaburova O, Santos S, Carvalho C, Azeredo J, Krylov V. 2010. Salmonella Enteritidis bacteriophage candidates for phage therapy of poultry. J Appl Microbiol. 108:1175-1186. doi: 10.1111/j.13652672.2009.04549.x.

Sillankorva S, Neubauer P, Azeredo J. 2008a. Isolation and characterization of a T7-like lytic phage for Pseudomonas fluorescens. BMC Biotechnol. 8:80. doi: 10.1186/1472-6750-8-80.

Sillankorva S, Neubauer P, Azeredo J. 2008b. Pseudomonas fluorescens biofilms subjected to phage philBB-PF7A. BMC Biotechnol. 8:79. doi: 10.1186/1472-6750-8-79. 
Steenackers H, Hermans K, Vanderleyden J, De Keersmaecker SCJ. 2012. Salmonella biofilms: an overview on occurrence, structure, regulation and eradication. Food Res Int. 45:502-531. doi: 10.1016/j.foodres.2011.01.038.

Stubbendieck RM, Straight PD. 2016. Multifaceted interfaces of bacterial competition. J Bacteriol. 198:2145-2155. doi: 10.1128/JB.00275-16.

Sukumaran AT, Nannapaneni R, Kiess A, Sharma CS. 2015. Reduction of Salmonella on chicken meat and chicken skin by combined or sequential application of lytic bacteriophage with chemical antimicrobials. Int J Food Microbiol. 207:8-15. doi: 10.1016/j.ijfoodmicro.2015.04.025.

Taylor R, Maryan C, Verran J. 1998. Retention of oral microorganisms on cobalt-chromium alloy and dental acrylic resin with different surface finishes. J Prosthet Dent. 80:592-597. doi: 10.1016/S0022-3913(98)70037-X.

Tokman JI, Kent DJ, Wiedmann M, Denes T. 2016. Temperature significantly affects the plaquing and adsorption efficiencies of Listeria phages. Front Microbiol. 7:1-10. doi: 10.3389/fmicb.2016.00631.

Tsuno H, Hidaka T, Nishimura F. 2002. A simple biofilm model of bacterial competition for attached surface. Water Res. 36:996-1006. doi: 10.1016/S0043-1354(01)00291-3.

USDA and Food Safety and Inspection Service. 2014. Chicken from farm to table. [accessed 2017 Sep 19]. https://www.fsis.usda.gov/wps/wcm/connect/ad74bb8d-1dab49c1-b05e-390a74ba7471/Chicken_from_Farm_to_Table. pdf?MOD=AJPERES
USDA and Food Safety and Inspection Service. 2015. Basics for Handling Food Safely. [accessed 2017 May 29]. http://www.fsis.usda.gov/wps/portal/fsis/topics/food-safetyeducation/get-answers/food-safety-fact-sheets/safe-foodhandling/basics-for-handling-food-safely/ct_index

Warren JC, Hatch MT. 1969. Survival of T3 coliphage in varied extracellular environments. I. Viability of the coliphage during storage and in aerosols Appl Microbiol. 17:256-261.

World Health Organization (WHO). 2015. WHO estimates of the global burden of diseases - foodborne disease burden epidemiology reference group 2007-2015. Geneva: World Health Organization.

World Health Organization (WHO). 2018. Salmonella (nonthypoidal). [accessed: 2018 Jan 29]. http://www.who.int/en/ news-room/fact-sheets/detail/salmonella-(non-typhoidal)

Wilkins MR, Gasteiger E, Bairoch A, Sanchez JC, Williams KL, Appel RD, Hochstrasser DF. 1999. Protein identification and analysis tools in the ExPASy server. Methods Mol Biol. 112:531-552. doi: 10.1385/1592595847.

Woody MA, Cliver DO. 1995 Effects of temperature and host cell growth phase on replication of F-specific RNA coliphage Q beta. Appl Environ Microbiol. 61:1520-1526.

Zhang Y and Hu Z. 2013. Combined treatment of Pseudomonas aeruginosa biofilms with bacteriophages and chlorine. Biotechnology and Bioengineering. 110:286-295. doi: 10.1002/bit.24630.

Zuker M. 2003. Mfold web server for nucleic acid folding and hybridization prediction. Nucleic Acids Res. 31:3406-3415. doi: 10.1093/nar/gkg595. 